\title{
Precancerous niche (PCN), a product of fibrosis with remodeling by incessant chronic inflammation
}

\author{
Björn L.D.M. Brücher ${ }^{1,2,3,}{ }^{*}$, Ijaz S. Jamall ${ }^{1,2,4}$ \\ ${ }^{1}$ Theodor-Billroth-Academy ${ }^{\circledR}$, Germany, USA \\ ${ }^{2}$ INCORE, International Consortium of Research Excellence of the Theodor-Billroth-Academy ${ }^{\circledR}$, Germany, USA \\ 3 Department of Surgery, Carl-Thiem-Klinikum, Cottbus, Germany \\ ${ }^{4}$ Risk-Based Decisions Inc., Sacramento, CA, USA
}

Received 22 March 2018, Accepted 19 December 2018

\begin{abstract}
Fibroblasts are actively involved in the creation of the stroma and the extracellular matrix which are important for cell adhesion, cell-cell communication, and tissue metabolism. The role of fibrosis in carcinogenesis can be examined by analogy to tissues of various cancers. The orchestration of letters in the interplay of manifold components with signaling and crosstalk is incompletely understood but available evidence suggests a hitherto underappreciated role for fibrosis in carcinogenesis. Complex signaling and crosstalk by pathogenic stimuli evoke persistent subclinical inflammation, which in turn, results in a cascade of different cell types, ubiquitous proteins and their corresponding enzymes, cytokine releases, and multiple signaling pathways promoting the onset of fibrosis. There is considerable evidence that the body's attempt to resolve such a modified extracellular environment leads to further disruption of homeostasis and the genesis of the precancerous niche as part of the six-step process that describes carcinogenesis. The precancerous niche is formed and can be understood to develop as a result of (1) pathogenic stimulus, (2) chronic inflammation, and (3) fibrosis with alterations of the extracellular matrix, stromal rigidity, and mechano-transduction. This is why carcinogenesis is not just a process of aberrant cell growth with damaged genetic material but the role of the PCN in its entirety reveals how carcinogenesis can occur without invoking the need for somatic mutations.
\end{abstract}

Keywords: Cancer, Carcinogenesis, Cell transition, Chronic inflammation, Epidemiology, Epigenetics, Fibrosis, Genomics, microRNA, Mutation, Pathogenesis, Precancerous niche, Proteomics, Somatic mutation theory

\section{Introduction}

Fibroblasts are actively involved in the creation of the stroma and the extracellular matrix (ECM), which is important for cell adhesion, cell-cell communication, and tissue metabolism. The orchestration of letters in the interplay of manifold components with fibroblasts along with signaling and crosstalk with varied constituents are incompletely understood but suggest a hitherto underappreciated role in carcinogenesis.

The importance of fibrosis in carcinogenesis can be seen by analogy in that "atrophic gastric mucosa is not just a case of simple atrophy but can be in some respects compared to a cirrhotic organ" [1].

Helicobacter pylori ( $H$. pylori) promotes hepatic fibrosis in animal models [2] by sensitizing transforming growth factor- $\beta 1$ (TGF- $\beta 1$ ) resulting in inflammatory

\footnotetext{
*Corresponding author: b-bruecher@gmx.de
}

signaling [3]. H. pylori lysates promote the translocation of nuclear factor kappa-light-chain enhancer of activated $\mathrm{B}$ cells $(\mathrm{NF}-\kappa \mathrm{B})$ into the nucleus in the presence of TGF- $\beta 1$, as hydrogen peroxide $\left(\mathrm{H}_{2} \mathrm{O}_{2}\right)$ treatment induces proliferation of hepatic stellate cell (HSC) lines from rats [3]. The prevalence of $H$. pylori is elevated in Opisthorchis viverrini associated with cholangiocellular carcinoma (CCC), with correlation to biliary periductal fibrosis [4]. Co-infection of hepatitis $\mathrm{C}$ virus ( $\mathrm{HCV}$ ) with $H$. pylori was common in up to $62 \%$ and with higher rates of lymphocytic infiltration. Fibrosis and cirrhosis were observed in coinfected groups compared to HCV infection alone, revealing that infections associated with both $\mathrm{HCV}$ and $H$. pylori result in an exacerbation of inflammation and fibrosis [5]. Furthermore, Opisthorchis felineus (O. felineus) was recently shown in a rodent model to be associated with chronic inflammation, fibrosis with all its changes, and consequent intrapeithlial neoplasia to directly induce a precancerous niche (PCN) facilitating malignancy [6]. 
The interplay of inflammation-triggered lesions, oral submucosal fibrosis (OSMF) and/or ubiqouitous proteins such as vimentin, are important in carcinogenesis. Investigating paraffin-embedded tissue sections of $n=208$ OSMF and $n=222$ oral squamous cell carcinoma (OSCC) yielded positive results for the presence of human papilloma virus 16 (HPV-16) in $25.96 \%$ and $1.92 \%$, respectively and of human papilloma virus 18 (HPV-18) in OSMF in $32.43 \%$ of HPV-16 positive cases and $12 \%$ in HPV-18 positive cases in OSCC [7]. Overall, the staining intensity of vimentin was greater in precancerous OSMF compared to a control group of normal buccal mucosa and this phenomenon was also demonstrated in fibroblasts [8].

\section{Fibroblasts}

Chronically activated fibroblasts secrete multiple proinflammatory cytokines (Fig. 1) such as TGF- $\beta 1$, interleukin 1 beta (IL-1 $\beta$ ), interleukin 6 (IL-6), interleukin

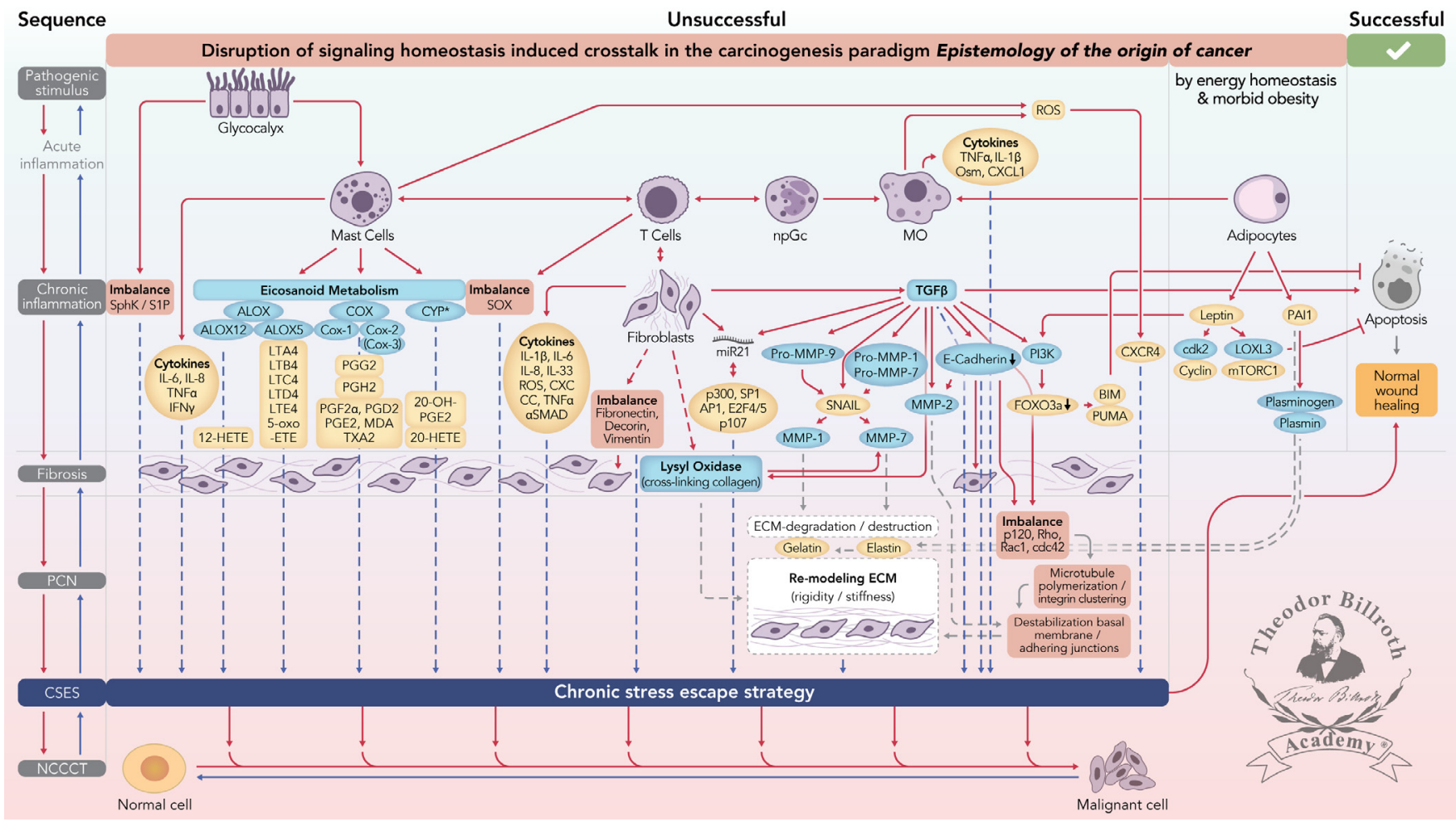

Fig. 1. Disruption of signaling homeostasis induced crosstalk in the carcinogenesis paradigm "Epistemology of the origin of cancer". Simplified scheme of the Disruption of signaling homeostasis induced crosstalk in the carcinogenesis paradigm "Epistemology of the origin of cancer" consisting of a 6-step sequence (1) a pathogenic stimulus followed by (2) chronic inflammation from which develops (3) fibrosis with associated remodeling of the cellular microenvironment; and from these changes a (4) precancerous niche (PCN), a product of fibrosis, with remodeling by persistent inflammation, develops which triggers the deployment of (5) a chronic stress escape strategy and when this fails resolve it by (6) normal cell to cancerous cell transition (NCCCT) by PCN-induced cell matrix stress occurs. This figure was published as original illustration in paper 3 of this Special Issue-Disruption of homeostasis-induced signaling and crosstalk in the carcinogenesis paradigm "Epistemology of the origin of cancer" entitled "Chronic inflammation evoked by pathogenic stimulus during carcinogenesis". We point out, that to the complexity of the content of the Special Issue the original and/or modified version of the original illustration was republished within the following papers of the Special Issue: paper 5 "Microbiome and morbid obesity increase pathogenic stimulus diversity", paper 6 "Precancerous niche (PCN), a product of fibrosis with remodeling by incessant chronic inflammation", paper 7 "Metformin alters signaling homeostasis", paper 8 "Transition from normal to cancerous cell by precancerous niche (PCN) induced chronic cell-matrix stress" and paper 9 "NF-кB signaling and crosstalk during carcinogenesis". Nomenclature: The nomenclature common abbreviations are bold, followed by the common trivial names (if available) and (if available) by the name in accordance to the International Union of Pure and Applied Chemistry (IUPAC): PCN precancerous niche; CSES chronic stress escape strategy; NCCCT normal cell to cancerous cell transition; SphK sphingosine kinase isoform; S1P sphingosine-1-phosphate; IL-6 interleukin 6; IL-8 interleukin 8; TNF $\boldsymbol{\alpha}$ tumor necrosis factor alpha; IFN $\boldsymbol{\gamma}$ interferon gamma; ALOX lipoxygenase, arachidonate lipoxygenase; ALOX12 12-lipoxygenase, 12-LOX, 12S-LOX, arachidonate 12lipoxygenase 12S type; ALOX5 5-lipoxygenase, 5-LOX, arachidonate 5-lipoxygenase; 12-HETE 12-hydroxyeicosatetraenoic acid; LTA4 leukotriene A4, 4-[(2S,3S)-3-[(1E,3E,5Z,8Z)-tetradeca-1,3,5,8-tetraenyl]oxiran-2-yl]butanoic acid; LTB4 leukotriene B4,(5S,6Z,8E,10E, 12R,14Z)-5,12-dihydroxyicosa-6,8,10,14-tetraenoic acid; LTC4 leukotriene C4,(5S,6R,7E,9E, 11Z,14Z)-6-[(2R)-2-[[(4S)-4-amino-4-carboxybutanoyl]amino]-3-(carboxymethylamino)-3-oxopropyl]sulfanyl-5-hydroxyicosa-7,9,11, 14-tetraenoic acid; LTD4 leukotriene D4, (5S,6R,7E,9E,11Z,14Z)-6-[(2R)-2-amino-3-(carboxymethylamino)-3-oxopropyl]sulfanyl-5-hydroxyicosa-7,9,11,14-tetraenoic acid; LTE4 leukotriene E4, (5S,6R,7E,9E,11Z,14Z)-6-[(2R)-2-amino-2-carboxyethyl]sulfanyl-5-hydroxyicosa-7,9,11,14-tetraenoic acid; 5-oxo-ETE (6E,8Z,11Z,14Z)-5-oxoicosa-6,8,11,14-tetraenoic acid; Cox cyclooxygenase; Cox-1 cyclooxygenase 1; Cox-2 cyclooxygenase 2; Cox-3 
33 (IL-33), reactive oxygen species (ROS), C-X-C chemokine receptor (CXC), chemokines (CC) $[9,10$ reviewed in 11], metalloproteinases (MMPs) [12], lysyl oxidase [13], microRNA 21 (miR21) indirectly triggered by transforming growth factor- $\beta$ (TGF- $\beta$ ) [14] or tumour necrosis factor $\alpha(\mathrm{TNF} \alpha)$ with alpha-smooth muscle actin $(\alpha \mathrm{SMA})[15]$.

Fibroblasts are instrumental in fueling the process of subclinical inflammation [16].

Fibrosis is a complex series of events and involves, among other things, an imbalance of fibronectin, decorin, and vimentin. Fibronectin activates Toll-like receptor 4 (TLR-4) on macrophages, a pathway usually used by lipopolysaccharides [17]. Decorin has two opposing effects: one repressing TGF- $\beta 1$ effects and the other influencing cell behavior by auto- and paracrine pathways there is growing evidence that the signaling pathways for EGF receptors and decorin become desensitized through a decrease in the number of receptor molecules [18 reviewed in 19]. Despite the regulatory effects of decorin on collagen fibrillogenesis, decorin can reverse the effect of TGF- $\beta 1$ with a net result of increasing "IL-1 $\beta, I L 6, T N F \alpha$, inducible nitric oxide synthetase (NOS), and the expression of major histocompatibility complex class II genes" $[20$ reviewed in 21]. "Overexpression of certain extracellular matrix proteins (such as decorin) during the ongoing desmoplastic reaction in chronic pancreatitis may be the cause of the altered behaviour of mononuclear cells, thus continuously maintaining the inflammatory process" [21]. However, increased decorin levels in transgenic mice do not repress TGF- $\beta 1$ in the liver [22]. Furthermore, decorin specifically promotes monocyte chemoattractant protein-1 (MCP-1) in mononuclear cells and appears to be necessary for "continuous MCP-1 mediated recruitment of non-optimally activated macrophages and lymphocytes" [21].

Chronic activation of fibroblasts, and their interaction with mast cells (Fig. 1) results in the release of metalloproteinase 9 (MMP-9) [23]. Snail stabilization occurs through protein kinase B (Akt, PKB)/glycogen synthase kinase 3 beta (GSK-3 $\beta$ ) signaling after TNF $\alpha$ induced epithelial mesenchymal transition (EMT) in prostate cancer cells [24] as well as hypoxia inducible factor 1 alpha (HIF-1 $\alpha)[25]$.

Interestingly, increased phosphatidylinositide 3-kinase $(\mathrm{PI} 3 \mathrm{~K}) /$ Akt /glycogen synthase kinase 3 beta (GSK-3ß) signaling with "elevated Snail protein level was also observed in hepatocellular carcinoma (HCC) tumor tissues with intrahepatic metastasis or chronic hepatitis $B$ virus (HBV) infection" [26]. Both myofibroblasts and activated macrophages induce Angiotensin-II during fibrosis which promotes " $T G F-\beta$-mediated cardiac remodeling" [23,27]. Even TNF $\alpha$-induced EMT requires Akt/ GSK-3 $\beta$-mediated stabilization of Snail in colorectal cancer (CRC) [28].

The glycogen serine-threonine kinase and negative regulator of the oncogenic Wnt/ $\beta$-catenin signaling pathway, glycogen synthase kinase $3 \beta$ (GSK-3 $\beta$ ) is increased in chronic inflammation. Inhibition of GSK$3 \beta$ in vitro results in a shift from NF- $\mathrm{KB}$ activity toward cAMP response element-binding protein (CREB) activity [29]. GSK-3 $\beta$ regulates cyclooxygenase 2 (Cox-2) expression in gastric cancer cells but GSK-3 $\beta$ inhibition stimulates only a modest Cox- 2 expression [30], which might explain why Cox-2 inhibition can also result in GSK-3 $\beta$ increase with an anti-tumor effect. GSK-3 $\beta$ was shown to be essential in early pancreatitisinduced acinar-to-ductal metaplasia as GSK-3 $\beta$ ablation limited the acinar-to-ductal metaplasia [31]. Increased GSK-3 $\beta$ expression is associated with the lesion grade in cervical cancer and inversely correlated with Cyclin D1 [32]. Dextran sulfate sodium (DSS)induced intestinal fibrosis was improved via GSK-3 $\beta$ signaling and after the use of the peroxisome proliferator-activated receptor gamma (PPAR- $\gamma$ ) modulator, GED-0507-34 Levo [33].

The carcinogen, hexavalent chromium (Cr VI), induces PI3K /Akt-dependent activation of GSK-3 $\beta$ / $\beta$-catenin signaling [34]. GSK-3 $\beta$ induces adenomatous

isoform of Cox-2 (therefore in brakes); PGG2 prostaglandin G2, (Z)-7-[(1S,4R,5R,6R)-5-[(E,3S)-3-hydroperoxyoct-1-enyl]-2,3-dioxabicyclo [2.2.1]heptan-6-yl]hept-5-enoic acid; PGH2 prostaglandin H2, (Z)-7-[(1S,4R,5R,6R)-5-[(E,3S)-3-hydroxyoct-1-enyl]-2,3-dioxabicyclo [2.2.1]heptan-6-yl]hept-5-enoic acid; PGFF2 $\boldsymbol{\alpha}$ prostaglandine F2 alpha, (Z)-7-[(1R,2R,3R,5S)-3,5-dihydroxy-2-[(E,3S)-3-hydroxyoct-1-enyl]cyclopentyl]hept-5-enoic acid; PGD2 prostaglandin D2, (Z)-7-[(1R,2R,5S)-5-hydroxy-2-[(E,3S)-3-hydroxyoct-1-enyl]3-oxocyclopentyl]hept-5-enoic acid; PGE2 prostaglandin E2, (Z)-7-[(1R,2R,3R)-3-hydroxy-2-[(E,3S)-3-hydroxyoct-1-enyl]-5oxocyclopentyl]hept-5-enoic acid; MDA malondialdehyde, propanedial; TXA2 thromboxane A2, (Z)-7-[(1S,2S,3R,5S)-3-[(E,3S)3-hydroxyoct-1-enyl]-4,6-dioxabicyclo[3.1.1] heptan-2-yl] hept-5-enoic acid; CYP* cytochrome P450 isoforms; 20-OH-PGE2 20hydroxy prostaglandin E2; 20-HETE 20-hydroxyeicosatetraenoic acid, (5Z,8Z, 11Z,14Z)-20-hydroxyicosa-5,8,11,14-tetraenoic acid;

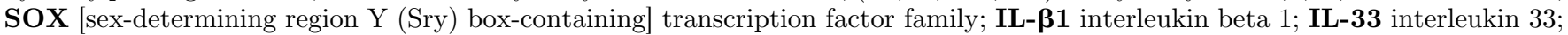
ROS reactive oxygen species; CXC CC chemokine receptors; $\boldsymbol{\alpha S M A D}$ alpha-smooth muscle actin; miR21 micro RNA-21; p300 protein 300 (p300-CBP coactivator family); SP1 specificity protein 1; AP1 activator protein 1; E2F4/5 cytoplasmic complex of Smad3, retinoblastoma-like protein 1 (P107, RBL1), E2F4/5 and D-prostanoid (DP1); p107 retinoblastoma-like protein 1, RBL1; TGF $\beta$ transforming growth factor beta; Pro-MMP-9 pro-matrix metalloproteinase 9; Pro-MMP-1 pro-matrix metalloproteinase 1; Pro-MMP-7 pro matrix metalloproteinase 7; SNAIL zinc finger protein SNAI1; MMP-1 matrix metalloproteinase 1; MMP-7 matrix metalloproteinase 7; MMP-2 matrix metalloproteinase 2; E-Cadherin CAM 120/80 or epithelial cadherin, cadherin-1, epithelial cadherin; CXCL1 chemokine (C-X-C motif) ligand 1; Osm oncostatin-M; PI3K phosphatidylinositide 3-kinase; FOXO3a forkhead box protein O3a; p120 catenin delta-1, protein 120; Rho Ras homolog gene family, member A; Rac1 Ras-related C3 botulinum toxin substrate 1; cdc42 cell division control protein 42 homolog; BIM Bcl-2 interacting mediator of cell death; PUMA BH3-only protein; CXCR4 C-X-C motif of chemokine receptor 4; cdk2 cyclin-dependent kinase 2; LOXL3 lysyl oxidase homolog 3; mTORc1 rapamycin complex 1; PAI1 Plasminogen activator inhibitor-1. 
polyposis coli (APC) protein phosphorylation with decreased APC-microtubules interactions and destabilization of the cellular cytoskeleton [35].

Focal adhesion kinase (FAK) activity is elevated in human pancreatic ductal adenocarcinoma (PDAC) tissues, and correlates with poor CD8+ cytotoxic T cell infiltration and high levels of fibrosis [36]. It seems logical, therefore, that this would constitute a key step in the creation of the PCN and may explain how the PCN contributes to the poor response to immunotherapy in pancreatic cancer. Supporting evidence comes from the use of the FAK inhibitor, VS-4718, limiting tumor progression which was associated with markedly reduced fibrosis and decreased numbers of tumor-infiltrating immunosuppressive cells, resulting in a doubling of survival time in a mouse model [36].

Carcinogenesis is often described as a process of cell growth gone awry with external factor(s) having damaged the genetic material of the cell, i.e. caused somatic mutations. However, in our view, consideration needs to be given to how a cell or tissue responds to an internal/external provocation. Thus, we hold that the tumor microenvironment plays an important role in carcinogenesis as shown by the identification of a multifactorial cytokine loop in bladder cancer in vitro: fibroblast-induced interleukin 8 (IL-8), hepatocyte growth factor (HGF), matrix metalloproteinase-2 (MMP-2), granulocyte macrophage colony-stimulating factor (gmCSF), and MCP-1 act together to facilitate metastasis [37].

Fibroblasts activation is known to trigger the deposition of ECM compounds such as vimentin, with $\alpha$ SMA resulting in the fibronectin matrix, linking both cells and collagen bundles [38]. We suggest that the imbalance of compounds such as fibronectin, decorin, and vimentin with ongoing fibrosis is of importance in carcinogenesis. Fibrogenesis, through aberrant accumulation and activation of myofibroblasts, triggers the deposition of ECM components and initiates tissue remodeling [38] with increased stiffness analogous to that seen in pulmonary or liver fibrosis that occurs prior to, for example, asbestos-induced mesotheolioma or smoking-associated lung cancer $[39,40]$.

Matrix stiffening also stimulates the proliferation of fibroblasts with increased matrix synthesis [41]. This was shown in normal tissue with a "...stiffness-driven suppression of cyclooxygenase-2 (Cox-2) expression and prostaglandin E2 (PGE2) as a key link between matrix stiffening and fibroblast activation". Cytokines and TGF- $\beta$ cause fibroblasts within the matrix to modulate ECM, including $\alpha$ SMA expression [42]. $\alpha$ SMA expression is induced by TGF- $\beta$ [43] Syndecan-4 is also necessary for transduction of signals through protein kinase $\mathrm{C}$ alpha $(\mathrm{PKC} \alpha)$ activation resulting in the assembly of the actin cytoskeleton, cell contractility, and metastasis [44]. A Bleomycin model of fibrosis resulted in a 6 -fold increased tissue stiffness compared to normal lung tissue. In normal tissue, PGE2 results in fibroblast quiescence including a feedback pathway between matrix stiffening, Cox-2 suppression, and fibroblast activation in the development of fibrosis [41]. This cascade, when perpetuated, could explain how fibrogenesis can shift into a selfsustaining phase.

Fibroblasts are involved in creation of the PCN (Fig. 1). This process is supported by exosome releases (small vesicles) that activate the chemoresistance-inducing factor Snail in epithelial cells, promote proliferation, and induce drug resistance [45].

There is a renewed interest in assessing the contribution of inflammatory processes as prognostic variables in cancers [46]. The sequences (1) pathogenic stimulus, (2) chronic inflammation, (3) fibrosis and (6) normal to cancer cell transition are seen in viral hepatitis-associated liver cancer [47]. It also appears that ongoing pathogenic stimuli may result in epigenetic silencing and thereby increase virulence [48].

\section{TGF}

The TGF- $\beta$ family of receptors specific for TGF- $\beta$ include, TGF- $\beta$ R1 (ALK5), TGF- $\beta$ R2 and TGF- $\beta$ R3 ( $\beta$-glycan); TGF- $\beta R 1$ and TGF- $\beta R 2$ have a high affinity for TGF- $\beta 1$ and low affinity for TGF- $\beta 2$ while TGF- $\beta$ R3 has a high affinity for both homodimeric TGF- $\beta 1$ and TGF- $\beta 2$. TGF- $\beta 1$ ligand binds to either TGF- $\beta$ RIII or TGF- $\beta$ RII, which aggregates with TGF- $\beta$ RI and phosphorylates TGF- $\beta$ RI resulting in the transmembranous phosphorylation of Smad-2 and Smad3 by the serinethreonine kinase activity of TGF- $\beta$ RI [49-52]. This builds up a complex with Smad4 allowing the complex to migrate into the nucleus [53]. Once inside the nucleus, (together with other factors), transcription is initiated. Increased stromal TGF- $\beta$ gene expression has been associated with poor prognosis in CRC [54]. Investigating the mRNA expression of TGF- $\beta 1$, Smad4, and apoptosis-inducing Smad7 in 97 samples of esophageal squamous cell carcinoma (ESCC) biopsies taken before neoadjuvant radiochemotherapy revealed that only Smad4 had predictive value in regard to patient survival [53].

It is known that proteasomic activity is higher in tumors [55]. The degradation of TGF- $\beta 1$ receptors occurs by the ubiquitin E3 ubiquitin-protein ligase (Smurf2) and that post-transcriptional factors may alter the activity of genes [53]. A negative influence on this transcriptional complex is achieved by inhibitors such as the nuclear proto-oncogene 'Sloan Kettering Institute' (Ski), the Skinovel protein (SnoN) [56,57], the Smad transcriptional corepressor $\mathrm{T}$ cell growth inhibitory factor (TGIF) [58] and positive influences by the stimulation via Runx proteins [59].

As a result of transcription, the synthesis of inhibitors of the cell cycle, i.g.p15, p21 and the inhibition of the proliferation and apoptosis-induced protein, c-myc occurs [60]. A disruption of the complete TGF- $\beta$ cascade takes place via phosphorylation of Smad3 by CDC2-kinasis and initiates the cell-cycle to proceed to the transition G1-/ S-phasis [61]. 
TGF-ß1-induced apoptosis (Fig. 1) occurs by indirect activation of mitogen-activated protein kinases (MAP kinases) [62-65] and can also be induced by apoptosis of Smad7 [63,66,67]. Gluthatione-S-transferase is also relevant as it inhibits members of the MAP kinase family by building up a protein-protein interaction. This suggests that increasing the glutathioneS-transferases $\pi$ level can lead to an inhibition of MAP kinases [68]. This model is supported by data from head and neck cancers [69].

Chronic TGF- $\beta 1$ triggers, independent of the TGF- $\beta$ receptor kinase, TGF- $\beta$ activated kinase 1 (TAK1) increasing collagen and fibronectin expression via MAPK and c-Jun N-terminal kinase (JNK) signaling [70]. TGF- $\beta 1$ promotes MAPK via activation of extracellular signal-regulated kinase 1 (Erk1, mitogen-activated protein kinase 3, MAPK3) and extracellular signalregulated kinase 2 (Erk2, mitogen-activated protein kinase 1, MAPK1) and increases the Ser-9-phosphorylated inactive form of GSK-3 $\beta$ and nuclear translocation of $\beta$-catenin [71]. Following the increases in fibronectin and vimentin by TGF- $\beta 1[72,73]$, there are increases in the zinc-finger transcription factor Snail through Smad3 [74].

The inhibition of heat-shock protein 27 (HSP27), highly expressed in fibrotic foci of idiopathic pulmonary fibrosis (IPF), results in Snail degradation followed by inhibition of TGF- $\beta 1$ induced cell transition [75]. TGF- $\beta 1$ stabilizes Snail and is associated with increased integrin $\beta 3$ with consequent high Akt activity and elevated inhibitory phosphorylation of GSK-3 $\beta[76,77]$.

The nerve growth factor, IB (NGFIB, Nur77 or NR4A1), was shown to negatively regulate TGF- $\beta 1$ suggesting the ability to limit pro-fibrotic TGF- $\beta$ effects [78]. Also, Nur77 was shown to promote breast cancer invasion and metastasis by activating TGF- $\beta$ signaling [79]. However, it was shown that the HCV core protein inhibits Nur77 and apoptosis [80] and that inhibition of apoptosis by Nur77 occurs through NF-кB [81]. These data demonstrate that the disruption of cellular homeostasis is of importance during carcinogenesis.

Snail stability and activity are activated by lysyl oxidase [82]. TGF- $\beta 1$ induces lysyl oxidase expression (Fig. 1), secretion, and proteolytic processing in normal as well as in mammary epithelial cells and lysyl oxidase downregulates the E-Cadherin suppressive effect [83] while upregulating vimentin [84,85]. Both the upregulation of vimentin and downregulation of E-Cadherin were observed at the mRNA level [86].

TGF- $\beta 1$ increases accumulation of all forms of lysyl oxidase proteins which are usually decreased by PGE2 [86]. "Much of the PGE2 action on the expression of type I collagen alpha1, lysyl oxidase, and Cox-1 genes is mediated through the prostaglandin E2 (EP2) receptor and a subsequent increase in intracellular cAMP [87].

Blocking TGF- $\beta$ on the surface of regulatory T cells $\left(\mathrm{T}_{\mathrm{Reg}}\right)$ increases programmed cell death protein 1 (PD1) on $\mathrm{CD} 8+\mathrm{T}$ cells, which may suggest a role for $T_{\text {Reg }}$ in cancer therapy [88]. Even in rare small bowel carcinomas significant associations between mRNA levels for Cox-1, Cox-2, TGF- $\beta 1$, prostaglandins of $\mathrm{E}$ class (PGEs), and pro-angiogenic factors, vascular endothelial growth factor A (VEGF-A) and vascular endothelial growth factor C (VEGF-C) are likely to play a role in carcinogenesis [89]. Different vascular endothelial growth factors (VEGFs) seem to have different and specific effects in carcinogenesis and in disease progression depending on the histological subtype. VEGF-C plays a role during progression via lymphangiogenesis in ESCC, while this effect was not observed in esophageal adenocarcinomas [90].

\section{E-cadherin (Fig. 1)}

TGF- $\beta$ represses E-cadherin (Fig. 1) and occludin thereby facilitating disassembly of the adherens junction [91] and also stimulates matrix metalloproteinase-7 (MMP-7, pump-1 protease, PUMP 1), both mRNA and proteins, facilitating invasive behavior in glioma cells [92].

In renal tubular epithelial cells, TGF- $\beta 1$ triggered nuclear translocation of $\beta$-catenin and transcriptional induction of Slug resulting in a decrease of E-cadherin transcription [93]. E-cadherin suppresses uncontrolled cancer cell growth [94] while upregulation of Twist and $\mathrm{N}$-cadherin results in increased invasion in TGF- $\beta 1$ stimulated CCC cells [95].

\section{PI3K (Fig. 1)}

TGF- $\beta$ activates the PI3K / Akt (Fig. 1) pathway $[96,97]$. This action of TGF- $\beta$ is dependent on the activity of the E3 ubiquitin ligase tumor necrosis factor receptorassociated factor 6 (TRAF6) and complex formation of TGF- $\beta$ type I receptor (T $\beta R I$ ), including p85 $\alpha$ [97]. Furthermore, it increases connective tissue growth factor (CTGF, CCN2) [96]. CTGF, discovered in 1991 [98], is thought to modulate the cell-matrix-interaction by modifying the phenotype. Importantly, inhibiting CTGF can reverse fibrosis [99].

Lysyl oxidase activates PI3K [100] and both, lysyl oxidase and MMPs, are induced by TGF- $\beta$ [101]. Furthermore, lysyl oxidase triggers PI3K/Akt signaling $\mathrm{HIF}-1 \alpha$ protein synthesis and HIF-1 $\alpha$ increases lysyl oxidase in vitro and in vivo demonstrating that lysyl oxidase and HIF-1 $\alpha$ synergistically trigger remodeling of the ECM [100] plausibly creating the PCN [102,103]. More importantly, lysyl oxidase-induced HIF-1 $\alpha$ expression was shown not to be restricted to colon cancer cells only but also was observed in primary human fibroblasts [Supplementary Fig. S2C in 100].

PIK3/Akt signaling activates Rheb and rapamycin complex 1 (mTORC1) at the lysosome [104]. Mammalian target of rapamycin (mTOR) is known to contribute to cell growth and proliferation and to cancer [105-107].

Continuously increased levels of TNF- $\alpha$ activate IKK, the inhibitor of nuclear factor $\kappa \mathrm{B}$ (ІкB) kinase [108], and 
increased IKK $\beta$ activates mTOR signaling resulting in angiogenesis and tumor development [109]. HBV X protein $(\mathrm{HBx})$ upregulates mTOR pathway via IKK $\beta$ mediated inactivation of tuberous sclerosis complex 1 (TSC1) promoting increases in cell proliferation and VEGF production [108]. The phosphorylation of GSK-3 $\beta$ by Akt stabilizes Snail [110] which leads to an increase of TGF- $\beta$ induced Snail [111]. PI3K promotes chronic inflammation in adipose tissue with early insulin resistance [112].

\section{Forkhead box protein O3a (FOXO3a) (Fig. 1)}

Increased PI3K/AKT signaling is associated with decreased forkhead box protein O3a (FOXO3a) activity through phosphorylation, nuclear translocation and transcription [113]. The interactions of PI3K, FOXO3a, Bcl-2 mediator of cell death (Bim), and BH3-only protein (Puma) with its effect on apoptosis, are shown in Figure 1 (Erk-signaling is not included due to space limitations).

In vitro silencing of FOXO3a by transfection increases IL-8 levels in TNF-treated HT29 cells [114]. This pro-inflammatory effect was observed in pAktnegative primary breast cancer in which one key modulator of the inflammatory NF-кB, IкB kinase $\beta$ was increased and shown to be associated with decreased survival [115]. Decreased FOXO3a activity was also observed in patients with ulcerative colitis, an inflammatory condition [114] and gastric cancer with poor survival [116]. Paradoxically, increased FOXO3a in gastric cancer was associated with improved survival [117]. FOXO3a was more common in tumor samples than in adjacent normal tissues. FOX3a induces apoptosis via Bim signaling in bladder cancer cells T24 [118] and in breast cancer FOXO3a upregulates Bim-inducing apoptosis [119]. In breast cancer cells, the non-phosphorylated form of FOXO3a inhibits carcinogenesis and promotes apoptosis through upregulation of p27, Bim, and cleaved caspase 3 proteins [120]. However, here too, there is a disruption of homeostasis in multiple pathways leading to carcinogenesis as ERK downregulates (via MDM2 mediation) FOXO3a, inhibiting p27Kip1 and Bim transcription [120].

Puma is required for apoptosis [121] and is involved, independently of p53, in the induction of mast-cell death following cytokine deprivation in both mucosal-like and connective tissue-like mast cells [122]. As FOXO3a increases Puma [123], decreased FOXFO3a can be expected to result in the opposite effect and, via ERKsignaling, increase the downregulation of Bim and Puma with decreased apoptosis (Fig. 1).

\section{$\mathrm{E} 2 \mathrm{~F} 4 / 5$}

The cytoplasmic complex of Smad3, retinoblastomalike protein 1 (P107, RBL1), E2F4/5 and D-prostanoid
(DP1) moves to the nucleus aided by TGF- $\beta$ and with Smad4 repressing c-myc [124]. TGF- $\beta$ mediated c-myc response by the Smad-E2F4/5-p107 complex occurs in vitro about an hour after TGF- $\beta$ addition and this is described as a "cell cycle-independent event contributing to, rather than deriving from, G1 arrest'. TGF- $\beta$ promotes binding of Smad2/3, Smad4, p107, and the transcription factor E2F4/5 to the c-myc promoter in vivo and E2F4 and E2F5 repress transcription in combination with p107 or p130. E2F4/5 and p107 interact as "transducers of TGF$\beta$ receptor signals upstream of $c d k$ " [124]. The mechanism of silenced, repressed, or mutated c-myc associated with increased proliferation and cancer is incompletely understood as it has been shown that systemic c-myc repression can result in normal reversible regenerating tissue repressing Ras-induced lung tumors in mice [125].

The latent membrane protein 1 (LMP1) of EpsteinBarr virus (EBV) promotes chromosomal maintenance 1 (CRM1, Exportin1)-dependent nuclear export of E2F4/5 inhibiting p16INK4a-RB signaling resulting in lower cell cycle arrest [126].

\section{P107 (Fig. 1)}

TGF- $\beta$ triggers fast binding of $\operatorname{Smad} 2 / 3, \operatorname{Smad} 4$, $\mathrm{E} 2 \mathrm{~F} 4 / 5$, and p107 to the c-myc promoter in vivo [124]. The retinoblastoma protein family contains RB, p107 and $\mathrm{RB} 2 / \mathrm{p} 130$, named 'pocket proteins' for their molecular pocket for binding onto other proteins. RB binds to E2F keeping E2 promoter-binding-protein-dimerization partner (E2F-DP) inactivated and thus acts as a growth inhibitor preventing replication from the G1 to S-phase and also by reducing transcription of the S-phase by binding to a histone deacetylase (HDAC) protein. CDKand cyclin-dependent phosphorylated Rb (pRb) - which is found in the S, G2 and M-phases - results in the dissociation of $\mathrm{E} 2$ promoter-binding-protein-dimerization partner (E2F-DP) from Rb while entering the S-phase with consequent activation.

p107 (RBL1) [127] is ubiquitously expressed though with varying tissue distribution and levels of expression in different organs, primarily in breast and prostate epithelium and in B- and T-lymphocytes [128]. Proliferating human fibroblasts show increased levels of the tumor suppressor p107 [127] and E2F4-p107 complexes with decreased p130 levels [129]. E2F-4 binds selectively to hypo-phosphorylated tumor suppressor p107 [130] and p107 interacts with E2F controlling the F-box receptor Skp2 with consequent inhibition of cell proliferation and p27 stabilization [131].

The matrix protein, laminin $\mathrm{A} / \mathrm{C}$, is required for normal levels of pRB and p107 in mouse fibroblasts [132]. p107 represses SP1-mediated activation of fibroblast growth factor receptor 1 (FGFR1) and FGFR1 promoter activity in proliferating myoblasts. p107 interacts with the transcription factor SP-1 in myoblasts whereas p130 not; SP-1 directly interacts with the transcriptional complex consisting of E2F4 and p107 at the FGFR1 E2F4 binding site [133]. 
p107 was reported to be overexpressed in the early stages of CRC while it was lower in patients with metastasis [134] and higher nuclear p107 expression was shown in salivary gland tumors [135]. Otherwise, $\mathrm{pRb} / \mathrm{p} 107$-deficient mice frequently developed head and neck cancers as HPV-16 E7 transgenic mice, both with comparable phenotypes [136]. On the other hand, RB2/ p130 was involved in the development and progression of oral carcinomas [137,138], breast and endometrial cancer [139], lung cancer [140], nasopharyngeal carcinoma [141], lymphomas [142], and is a strong predictor of clinical outcome in endometrial carcinomas [143], and in HCC [144 reviewed in 145].

\section{MMPs (Fig. 1)}

In 1962, Woessner reported an enzyme that could degrade collagen [146 reviewed in 147] and whose biochemistry was elucidated by Gross and Lapiere in 1962 [148] following the purification of metalloproteinase 1 (MMP1) [149]. MMPs are calcium- and zinc-dependent endopeptidases synthesized as zymogens and released as proenzymes [150 reviewed in 147$]$.

MMPs degrade the ECM as well as its non-ECM proteins and are not cell-specific [147]. Their functionality has been extensively reviewed [151]. As MMPs regulate tumor suppression there is an opportunity for using anti-MMP therapy to treat cancer [152-154]. MMPs are activated by MMPs themselves (e.g., metalloproteinase 3, MMP3) as well as by plasmin, heparin, and intra- and extracellular protein degradation triggered by oxidants [147].

MMPs are inhibited by tissue inhibitors of metalloproteinase (TIMP) and $\alpha 2$-macroglobulins. In healthy tissues there is a balance between MMPs and TIMPs and disruption of this homeostasis results in abnormal tissue degradation. TIMP-1 inhibits all MMPs except metalloproteinase 14 (MMP-14) and has a greater affinity for metalloproteinase 9 (MMP-9) over MMP-2, while TIMP-2 exhibits a higher affinity for MMP-2 than MMP-9 [154, reviewed in 147, 151].

Neutrophils express TIMP-1, metalloproteinase 8 (MMP-8), MMP-9, and TIMP-1, and are predominantly localized to a distinct granules or vesicles within the neutrophil [155 reviewed in 147]. The interplay of gelatinases (matrix metalloproteinases MMP-2 and MMP-9) is complex, although simplified for illustration in Figure 1. Despite its role in remodeling the ECM, MMP-9 is activated by MMP-2 and metalloproteinase 3 (MMP-3). MMP-9 might be involved in tumor invasion, while MMP-2 appears to be involved in metastasis [156]. The disruption of homeostasis was seen with TIMP-1 within the stroma where increased TIMP-1 promoted liver metastasis by triggering HGF along with activating HGF and HGF-activating proteases [157].

Signaling by mast cells with T-cell interaction [158] induces neutrophils granulocytes (npGC) and macrophages with consequent induced cytokines and signaling pathways [159-161]. However, not all neutrophils trigger chronic inflammation as they undergo reverse transmigration, meaning that in situations where such cells do not die or are phagocytosed, they migrate via the lungs to up-regulate the C-X-C motif of chemokine receptor 4 (CXCR4) and end up in the bone marrow where they undergo apoptosis [162].

Increased levels of phosphoglycerate kinase 1 (PGK1), CXCR4, C-X-C motif chemokine 12 (CXCL12) and $\beta$-catenin are all associated with peritoneal carcinomatosis in gastric cancer patients [163]. PGK1 was shown to regulate CXCR 4 and $\beta$-catenin at the mRNA and protein levels with a negative feedback loop for CXCR4 [164]. This was observed in HCC [165]. Increasing evidence about the role of elevated CXCR4 levels in inflammation and cancer have been published [166-169] such that its use in identifying cancer therapy targets might be helpful [170] as CXRC4 also affects CXCR2, mitogen-activated protein kinase kinase (MEK, MAPK2, MAPKK), and PI3K signaling [171].

Expression profiles of MMPs have been correlated with poor clinical prognosis for several human tumor types [172]. The pro-invasive and metastasis-promoting activity of MMPs likely works through ECM remodeling [152]. Tumor cell invasion can be reduced $[173,174]$ by endogenous MMPs together with disintegrin and metalloproteinase 10 (MMP-10, ADAM-10) [175] and TIMP-1 [176].

MMP-7 was discovered by Woessner [177] and facilitates the degradation of casein, fibronectin, and collagen type I, II, IV and V and, thereby, the breakdown of the ECM [178]. H. pylori cytotoxin-associated gene $(+)$ selectively increases MMP-7 in vitro and in vivo in gastric pre- and cancerous tissue [179]. Knocking down MMP-7 in mice increased $H$. pylori-induced gastric inflammation with elevated M1 macrophage markers, which also were reproducible in hyperplasia and dysplasia.

TGF- $\beta 1$ induces MMP- 2 upregulation with disruption of the basal membrane [180]. Interestingly, tetracycline [181] and doxycycline [182] can inhibit MMPs.

\section{Extracellular matrix and lysyl oxidase}

The macromolecular components of the non-cellular ECM consist of collagens, fibronectin, elastin, laminins, hyaluronan and proteoglycans [183]. Collagen is composed of three $\alpha$-chains which are (at least partially) folded to a triple-helix and there are 28 collagen types subdivided into nine families [184]. Lysyl oxidase converts lysine residues through oxidative deamination of peptidyl lysine in elastin and peptidyl lysine and hydroxylysine in collagen resulting in cross-links [185]. Fibrillar collagen consists of three $\alpha$-chains bund into a triple helix and each $\alpha$-chain has a $\mathrm{N}$-terminal and $\mathrm{C}$-terminal propeptide next to the $\mathrm{N}$ - and C-terminal telopeptide; this area is the one were modification of lysine into helical lysyl hydroxylase (Hyl) occurs by (telopeptidase) lysyl hydroxylase compared to proline modification which occurs in the triplehelix only - not at the N- and C-terminal telopeptides [reviewed in 184]. This results into di- or trivlant cross 
links and the conversion of lysine into 5-hydroxylysine (Hyl) in the $\alpha$-chains of procollagen are catalyzed by lysyl hydroxylases.

In collagen, one lysyl residue per chain of $\sim 10^{3}$ amino acids $^{4}$ is oxidized to the aldehyde allysine compared to $5-16$ lysyl residues per $10^{3}$ amino acids in elastin [186-191]. This results in various divalent and trivalent crosslinks [192]. The glycosylated lysyl oxidase propeptide (LOX-PP) is required for the proenzyme (proLOX) to exit from the endoplasmatic reticulum (ER) [193]. The abbreviation LOX in this context should not be mistaken for the 2nd available abbreviation of arachidonate lipoxygenase isoforms which are altogether different enzymes.

The extracellular copper-requiring enzyme, lysyl oxidase, is part of the lysyl oxidase family which includes four subsequently discovered LOX-like paralogs LOXL1, LOXL2, LOXL3 and LOXL4 [194-198]. These isoforms are encoded by various genes on chromosomes 5 , $15,8,2$, and 10 with different molecular weights, various protein sizes, are expressed differently in different tissues $[199,200]$, and seem to need fibroblasts [201].

Lysyl oxidase is synthesized as a $46-\mathrm{kDa}$ pro-enzyme by fibroblasts, undergoes $\mathrm{N}$-glycosylation which is then secreted as a 50-kDa N-glycosylated proenzyme [202] into the ECM and once there, is proteolytically transformed to a mature enzyme of $31 \pm 1 \mathrm{kDa}$ [203 reviewed in 204]. Li et al. provided "immunological, catalytic, and chemical evidence that this catalyst occurs and appears to function within the nuclei of fibrogenic cells" [204]. Lysyl oxidase activity is dependent on its co-factors, copper and lysyl tyrosyl quinone [205], and catalyzes aldehyde formation from lysine residues to $\alpha$-aminoadipidic- $\delta$-semialdehydes (allysines) in collagen and elastin precursors [206].

Lysyl oxidase increases myeloid lineage cells and is relevant for the recruitment of CD11b + cells followed by co-localization with fibronectin [207]. Lysyl oxidase is upregulated in fibrosis and in scleroderma [208], and its isoenzymes are expressed differently in different tissues [199]. This may be crucial to understanding different tumor biologies as well as the dynamics of different cancers.

Remodeling by lysyl oxidase occurs in cardiac hypertrophy aggravating angiotensin-II induced hypertrophy [209] and angiotensin-TGF- $\beta 1$ crosstalk was reported serving as an autocrine path in human cardiac hypertrophy $[27,210]$.

Lysyl oxidase was shown to act on the ECM in both the cytoplasm and nucleus [205 reviewed in 83]. Furthermore, lysyl oxidase imbues type I collagen with increased rigidity in the ECM-promoted proliferation of mammary epithelial cells in vitro [83] and stimulates collagen cross-linking and synthesis of fibronectin [207]. The crosslinking of collagen to elastin results in stromal rigidity and increased mechano-transduction [211,212]. Lysyl oxidase attenuated collagen IV at the basement membrane with consequent increase of adherent CD11b + cells and increased MMP-2 expression resulting in the degradation of collagen IV and increased CD11b + cell invasion [207].
Lysyl oxidase "increased matrix elastin synthesis by 40 $80 \%$ to that in control cultures in a dose-dependent manner" [213]. Early stage lung adenocarcinoma tissue with high lysyl oxidase expression exhibited poor survival rates [214].

An ongoing pathogenic stimulus with unresolved chronic inflammation and TGF- $\beta 1$ activation results in increased lysyl oxidase activity and increased ECM rigidity. HIF-1 $\alpha$ mediated lysyl oxidase expression is increased by hypoxia [207] which also promotes integrinmediated focal adhesion formation and PI3K signaling [215]. By contrast, integrin $\alpha 5$ expression in ESCC "was associated with the survival of patients with lymph node metastasis but did not influence the survival of patients without lymph node metastasis" [216].

Paradoxical findings [208,217] may be explained by the fact that various pathways can activate lysyl oxidase and its isoforms [218]. Activation of lysyl oxidase can occur through both tumor growth factor beta (TGF- $\beta 1$ ) with Smad and non-Smad JNK/AP-1 signaling can regulate lysyl oxidase through vascular cell adhesion molecule (VCAM-1), intracellular adhesion molecule (ICAM-1), and monocyte chemotactic protein (MCP-1) which may explain paradoxical findings based on the particular isoform.

The lysyl oxidase family is involved in various cellular processes such as cell motility, migration, signaling, regulation of transcription, altering chromatin condensation, and carcinogenesis [208 reviewed in 219]. Furthermore, lysyl oxidase generates chemotactic sensitivity to cells e.g. through oxidizing the cell surface protein betatype platelet-derived growth factor receptor (PDGFR- $\beta$ ) [220,221]. For example, LOXL1 and LOXL4 are reported to be epigenetically silenced by promoter methylation in bladder cancer cells and antagonizing both isoenzymes resulted in the decrease of colony formation ability and activation of Ras [222].

Lysyl oxidase modulates the ECM, cell migration and growth [223] and its activity is greater in human breast cancer than in normal tissues [224].

\section{Precancerous niche (PCN) (Fig. 1)}

Endometriosis is epidemiologically a precancerous state of ovarian cancer [225] and contains LOX-like protein $4[226,227]$ with increased TGF- $\beta 1$ and phosphorylated Smad3, decreased e-cadherin and increased staining of collagen I and lysyl oxidase [228]. Another important finding supporting the PCN as the key point for transition of a normal cell to cancer cell occurs in the cancer-resistant species, the blind mole rat or Spalax [229]. Application of chemical carcinogens to this animal resulted in healing without malignancy.

Increased lysyl oxidase expression was found at the cancer invasion front, and was observed in (so-called) reactive per-cancerous fibrosis of breast cancer [230]. We contend that such changes constitute the necessity for the PCN and thus for the transition of a normal cell to a cancer cell. 
In cancer-resistant species, precancerous lesions heal. The naked mole rat (Heterocephalus glaber) [231], as well as the subterranean blind mole rat (Spalax), show low activity of hyaluronan synthase 2 (HAS2) [229]. HAS2 is an important enzyme in the ECM, as it interacts with the leukocyte receptor $\mathrm{CD} 44$, and overexpression or increased extracellular hyaluronan was associated with decreased survival, and mediated tumor metastasis in vivo and in vitro in CRC [232,233], stomach [234], esophagus [235], breast [236-239], head and neck [240] and ovarian cancer [241].

Hyaluronan, together with CD44, plays a significant role in cell and cancer adhesion as well as providing a less dense matrix and stimulates cell motility and protection against pathogens [242-245].

Inhibiting HAS2 in an aggressive MDA-MB-231 breast cancer cell line inhibited initiation as well as progression of primary and secondary cancers [246].

Protein arginine methyltransferase 1 (PRMT1) is necessary for "TGF- $\beta$-induced SMAD3 activation through a mechanism similar to that of TGF- $\beta$-related bone morphogenetic protein (BMP) induced SMAD6 methylation, and thus promotes the TGF- $\beta$-induced EMT and epithelial stem-cell generation" [247]. SMAD7 inhibits the TGF- $\beta$-induced SMAD3 activation but PRMT1 induced SMAD 7 methlyation enables and facilitates TGF- $\beta$ signaling.

Species like the Heterocephalus glaber and Spalax seem to have found an effective anticancer strategy by inhibiting the PCN. The interplay of disruption of homeostasis can be seen as the blind mole rat, Spalax galili, which reveals higher proteasome activity with increased levels of markers for autophagy [248].

The inflammatory microenvironment promotes carcinogenesis [249]. Ongoing remodeling of ECM leads to the development of the PCN $[102,103]$. Inhibition of PCN formation with the anti-inflammatory and anti-fibrotic atrial natriuretic peptide (ANP) [250] as well as observations in viral hepatitis-triggered liver cancer, indicate that fibrosis and the PCN are necessary for the proposed sixstep sequence that describes carcinogenesis without invoking the need for somatic mutations $[102,103]$. This "network of macromolecules with distinctive physical, biochemical, and biomechanical properties" is the major component [251] as reported earlier [102]. Loss of E-cadherin is also associated with ongoing remodeling of the ECM [252] in creating the PCN.

Stimulus of the ECM with chronic release of P2Y2R and activation by nucleotides leads to ongoing THP-1 monocyte recruitment, and HIF-1 $\alpha$ overexpression with consistent release of lysyl oxidase crosslinking collagen, facilitates changes to the tumor microenvironment $[253,254]$, which then cause the changes that result in the formation of the PCN.

Lysyl oxidase-like-2 (LOXL2) overexpression in AsPC-1 and BxPC-3 cells enhanced cell transition and increased both migratory and invasive activities. This biochemical micromileu promotes and creates the PCN. Higher LOXL2 expression is associated with elevated
Snaill and cytokines [255] and with invasiveness of pancreatic cancer cells and low survival rates of pancreatic cancer patients [256]. Increase of LOXL2 was shown in biopsies of human tumors, fibrotic liver and lung tissues compared to healthy tissues [257].

LOXL2 activity results in fibrosis in non-alcoholic fatty liver disease (NAFLD) and is enhanced by insulin resistance [258]. Monoclonal anti-LOXL2 antibody AB0023 [259] were used [257] and decreased activated fibroblasts, desmoplasia and growth factors including cytokines and TGF- $\beta$ signaling.

Although increases of lysyl oxidase were shown in murine schistosomiasis some 25 years ago [260], an antilysyl oxidase approach was not investigated. Lysyl oxidase was expressed in Escherichia coli (E. coli) [261]. Lysyl oxidase homolog 2 (LOXL2) [262] was found in human lung fibrosis, bronchiolo-alveolar carcinomas, and in situ ductal breast tumors [263]. In S.mansoni-infected mice and in early stages of liver granuloma, the lysyl oxidase gene and LOX-like gene (LOXL) were upregulated. LOXL2 promotes Snail and decreases E-cadherin, both important for carcinogenesis and metastasis. Investigations of the ECM by atomic force microscopy showed that LOXL2 does not affect ECM properties [264]. Incubating oral epithelial cells with the natural di-thiol $\alpha$-Lipoic acid was shown "to modulate periodontal bacterial induced $N F-k B$ activation, pro-inflammatory gene expression and cytokine production" [265].

Pathologists recognize the phenomena of desmoplastic stroma in histopathologies of cancerous tissues, which is concordant with rigid fibrous and remodeled ECM and develops from unresolved chronic inflammation. That the PCN is an important step in carcinogenesis $[102,103]$ was recently addressed by Willumson et al. applying this microenvironment condition for potential use of liquid biopsy biomarkers investigating the PCN [266]. Other future diagnostic tools might include electrochemical nanobiosensors and microfluidic devices [267].

Creating a prognostic normogram of inflammatory fibrotic stroma was demonstrated in CCC by combining histopathological charcteristics together with CD3, CD4 and $\alpha$-smooth muscle actin ( $\alpha$-SMA) staining of tissue microarrays [268]. Tumor cells aggregate to fibroblasts which further drive the cascade of chronic inflammation, fibrosis, and remodeling [269].

The epithelial to mesenchymal cell transition (EMT) initiates the Golgi scaffolding protein, PAQR11-mediated complex promoting cell migration and metastasis [270]. Thus, cancer cell development as well as tissue invasion and metastasis are triggered by an inflammatory fibrotic stroma [271]. This is further supported by evidence that the combined inhibition of LOXL2 and TGF- $\beta 1$ receptor $(\mathrm{T} \beta \mathrm{R})$ activities by trihydrophenolics attenuated lung and cancer fibrosis [272].

Inhibiting or knockdown of lysyl oxidase results in decreased cell motility [273,274], ameliorates or even prevents of fibrosis [272,275-281], decreases cancer cell colonization with decrease or elimination of metastasis $[275,276,282]$, and prevents metastasis [207,283,284]. 
However, it is important to identify which isoform of the lysyl oxidase family is inhibited via which drug or cellular signaling component [285].

Thioacetamide (TAA)-induced fibrosis in mice was inhibited and advanced parenchymal biliary and non-biliary fibrosis was reversed by the use of antiLOXL2 monoclonal antibody, AB0023, which also promoted hepatic progenitor cell differentiation towards hepatocytes and attenuated ductular reaction [277]. Therapeutic approaches to attenuating fibrosis and antiinflammatory approaches, e.g., potential corneal wound healing could be helpful as the TGF- $\beta$ /Smad pathway of fibrosis in human keratocytes was inhibited effectively in vitro [286].

Inhibition of the PCN can be achieved in multiple ways as recently reported. Signaling of regulatory T-cells and its TGF- $\beta$ pathway was inhibited with neutralizing antibodies [88]. Stroma and remodeled ECM (i.e., the PCN), rather than the cancer cell itself, triggers cancer development as myeloid cell expression of EGFR, increased activation of STAT3, and expression of survivin in intestinal epithelial cells and expression of IL-6 in colon tissues. EGFR deletion from myeloid cells but not from intestinal epithelial cells protected mice from colitisinduced cancer [287]. Therefore, PCN rather than the cancerous cell itself triggers carcinogenesis. Lysyl oxidase functions as a tumor promoter in advanced high-grade serous ovarian cancer and in facilitating the cascade of events leading to metastasis [288]. Increased lysyl oxidase expression levels in laryngeal cancer are associated with lymph node and distant metastasis and poor patient outcome [289] and inhibition of lysyl oxidase decreases or prevents fibrosis, metastasis, cell migration and motility [273-285].

The role of chemical carcinogens in the tumor microenvironment and carcinogenesis had been reviewed in more detail within the following manuscript of this special issue "Chronic inflammation evoked by pathogenic stimulus during carcinogenesis" [290]. This paragraph as well as the other manuscripts of the Special Issue summarize the available evidence in carcinogenesis and explains that the onset of cancer involves chronic inflammation, fibrosis with its remodeling leading to the formation of the PCN induce chronic cell stress and a disruption of homeostasis such that cancer can result over decades in a subset of the exposed population.

The $\mathrm{PCN}$ is not just to be the starting point for how a normal cell to cancer cell transition occurs, and the process can be interdicted, but also explains why the completeness of radical cancer surgery as macroscopic and microscopic complete resections (R0-resection) needs to be changed in accordance to a local (paratumoral) or more distant precancerous niche (PCN). This even may provide a future need or basis for why (1) a different therapeutic approach may be of benefit for the patient's survival, progression free survival - with the goal of quality of life remaining being foremost [291] and even (2) why this would be of help in R0 resected patients who progress due to primary locally advanced cancer stages.

\section{Summary}

Ongoing pathogenic stimuli induces chronic inflammation [290,292], promotes fibrosis with its remodeled version, the PCN. Thus, the PCN explains why it is not just external stimuli that brings about carcinogenesis but the response of the host tissue [293] to such stimuli and the ability or inability of the host to interdict the pro-inflammatory pathways, signaling cascades [290,292], and fibrotic changes that describe the dysregulation of the cellular and tissue equilibrium (Fig. 1) which are, in toto, critical to carcinogenesis and, perhaps, equally important to the onset of metastasis. Significant in this context are the influence by the microbiome and obesity [294] as well as findings investigating a key enzyme, lysyl oxidase, its isoforms and receptors, as well as the study of cancer-resistant species. The remodeled ECM within the "Disruption of signaling homeostasis induced crosstalk in the carcinogenesis paradigm Epistemology of the origin of cancer" resulting in the PCN does not need a mutation to occur. Therefore, the proposed 6-step sequence is important for carcinogenesis and metastases.

\section{Nomenclature}

ADAM-10 A disintegrin and metalloproteinase 10, MMP 10

Akt Protein kinase B

alpha SMA Alpha-smooth muscle actin

ANP Atrial natriuretic peptide

APC Adenomatous polyposis coli protein

Bim

$\mathrm{CC}$

CCC

$\mathrm{CCN} 2$

Cox-1

Cox-2

CRC

CREB

CRM1

CTGF

CXC

CXCR4

DP1

EBV

ECM

EMT

EP2

BCL-2 interacting mediator of cell death

Chemokines

Cholangiocellular carcinoma

Connective tissue growth factor, CTGF

Cyclooxygenase-1 (=Prostaglandin $\mathrm{G} / \mathrm{H}$ synthetase 1)

Cyclooxygenase 2

Colorectal cancer

cAMP response element-binding protein Chromosomal maintenance 1, Exportin1

Connective tissue growth factor, CCN2

C-X-C chemokine receptor

C-X-C motif of chemokine receptor 4

D-prostanoid

Epstein-Barr virus

Extracellular matrix

Epithelial mesenchymal transition

PGE2 receptor

Erk1 Extracellular signal-regulated kinase 1, mitogen-activated protein kinase 3 , MAPK3

Erk2 Extracellular signal-regulated kinase 2, mitogen-activated protein kinase 1 , MAPK1 


\begin{tabular}{|c|c|}
\hline ESCC & Esophageal squamous cell carcinoma \\
\hline FAK & Focal adhesion kinase \\
\hline FGFR1 & Fibroblast growth factor receptor 1 \\
\hline FOXO3a & Forkhead box protein O3a \\
\hline gmCSF & $\begin{array}{l}\text { Granulocyte macrophage colony-stimu- } \\
\text { lating factor }\end{array}$ \\
\hline GSK-3 $\beta$ & Glycogen synthase kinase 3 beta \\
\hline HAS2 & Hyaluronan synthase 2 \\
\hline $\mathrm{HBx}$ & Hepatitis B virus (HBV) X protein \\
\hline $\mathrm{HBV}$ & Hepatitis B virus \\
\hline $\mathrm{HCC}$ & Hepatocellular carcinoma \\
\hline $\mathrm{HCV}$ & Hepatitis $\mathrm{C}$ virus \\
\hline HDAC & Histone deacetylase \\
\hline HGF & Hepatocyte growth factor \\
\hline HIF- $1 \alpha$ & Hypoxia inducible factor 1 alpha \\
\hline $\mathrm{HPV}$ & Human papilloma virus \\
\hline HPV16 & Human papilloma virus 16 \\
\hline HPV18 & Human papilloma virus 18 \\
\hline HSC & Hepatic stellate cell \\
\hline HSP27 & Heat-shock protein 27 \\
\hline IKK & Inhibitor of nuclear factor $\kappa \mathrm{B}(\mathrm{I} \kappa \mathrm{B})$ kinase \\
\hline IL-1 $\beta$ & Interleukin 1 beta \\
\hline IL-6 & Interleukin 6 \\
\hline IL-8 & Interleukin 8 \\
\hline IL-33 & Interleukin 33 \\
\hline IPF & Idiopathic pulmonary fibrosis \\
\hline JNK & c-Jun N-terminal kinase \\
\hline LMP1 & Latent membrane protein 1 \\
\hline LOX & Lysyl oxidase \\
\hline LOXL2 & Lysyl oxidase-like-2 \\
\hline MAP kinases & Mitogen-activated protein kinases \\
\hline MAPK3 & $\begin{array}{l}\text { Mitogen-activated protein kinase } 3 \text {, extra- } \\
\text { cellular signal-regulated kinase } 1 \text {, Erk1 }\end{array}$ \\
\hline MAPK7 & $\begin{array}{l}\text { Mitogen-activated protein kinase } 7 \text {, extra- } \\
\text { cellular signal-regulated kinase } 5 \text {, Erk } 5\end{array}$ \\
\hline MCP-1 & Monocyte chemoattractant protein-1 \\
\hline MEK & $\begin{array}{l}\text { Mitogen-activated protein kinase kinase, } \\
\text { MAPK2 }\end{array}$ \\
\hline MMP1 & Matrix metalloproteinase- 1 \\
\hline MMP-2 & Metalloproteinase 2 \\
\hline MMP-3 & Metalloproteinase 3 \\
\hline MMP-7 & $\begin{array}{l}\text { Matrix metalloproteinase- } 7 \text {, pump-1 pro- } \\
\text { tease (PUMP 1) }\end{array}$ \\
\hline MMP-8 & Matrix metalloproteinase- 8 \\
\hline MMP-9 & Metalloproteinase 9 \\
\hline MMP-10 & Matrix metalloproteinase-9 (ADAM-10) \\
\hline MMP-14 & Metalloproteinase 14 \\
\hline MMPs & Metalloproteinases \\
\hline mTOR & Mammalian target of rapamycin \\
\hline mTORC1 & Rapamycin complex 1 \\
\hline NAFLD & Non-alcoholic fatty liver disease \\
\hline NF-кB & $\begin{array}{l}\text { Nuclear factor kappa-light-chain enhancer } \\
\text { of activated B cells }\end{array}$ \\
\hline NGFIB & Nerve growth factor IB, Nur77 or NR4A1 \\
\hline npGC & Neutrophile granucolcyte \\
\hline NR4A1 & Nerve growth factor IB, Nu77 or NGFIB \\
\hline Nur77 & Nerve growth factor IB, NGFIB or NR4A1 \\
\hline NOS & Nitric oxide synthetase \\
\hline OSCC & Oral squamous cell carcinoma \\
\hline
\end{tabular}

$\begin{array}{ll}\text { OSMF } & \text { Oral submucosal fibrosis } \\ \text { p107 } & \text { Retinoblastoma-like protein 1 (RBL1) } \\ \text { PCN } & \text { Precancerous niche } \\ \text { PD-1 } & \text { Programmed cell death protein 1 } \\ \text { PDAC } & \text { Pancreatic ductal adenocarcinoma } \\ \text { PGE2 } & \text { Prostaglandin E2 } \\ \text { PGEs } & \text { Prostaglandins of E class } \\ \text { PGK1 } & \text { Phosphoglycerate kinase 1 } \\ \text { PI3K } & \text { Phosphatidylinositide 3-kinase } \\ \text { PKC } \alpha & \text { Protein kinase C alpha } \\ \text { PKB } & \text { Protein kinase B (=AKT) } \\ \text { PPAR- } \gamma & \text { Peroxisome proliferator-activated recep- } \\ \text { pRb } & \text { tor gamma } \\ \text { Puma } & \text { Phosphorylated Rb } \\ \text { ROS } & \text { BH3-only protein } \\ \text { Ski } & \text { Reactive oxygen species } \\ \text { Smurf2 } & \text { Institute' } \\ \text { SnoN } & \text { Ski-novel protein } \\ \text { TAA } & \text { Thioacetamide } \\ \text { TAK1 } & \text { TGF- } \beta \text {-activated kinase 1 } \\ \text { T } \beta R I & \text { TGF- } \beta \text { type I receptor } \\ \text { TGF- } \beta & \text { Transforming growth factor beta } \\ \text { TGF- } \beta 1 & \text { Transforming growth factor- } \beta 1 \\ \text { TIMP } & \text { Tissue inhibitors of metalloproteinase } \\ \text { TIMP1 } & \text { Tissue inhibitor of metalloproteinase 1 } \\ \text { TLR-4 } & \text { Toll-like receptor } 4 \\ \text { TNF } \alpha & \text { Tumour necrosis factor } \alpha \\ \text { TRAF6 } & \text { Tumor necrosis factor receptor-associated } \\ \text { TReg } & \text { factor } 6 \\ \text { VEGFs } & \text { Tegulatory T cells } \\ \text { VEGF-C } & \text { Vascular endothelial growth factors } \\ & \end{array}$

\section{Acknowledgements}

The manuscripts of this Special Issue were supported by the Theodor-Billroth-Academy ${ }^{\circledR}\left(\mathrm{TBA}^{\circledR}\right)$ and INCORE, (International Consortium of Research Excellence) of the $\left(\mathrm{TBA}^{\circledR}\right)$. We express our gratitude to the discussions on the web group of the Theodor-Billroth-Academy ${ }^{\circledR}\left(\mathrm{TBA}^{\circledR}\right)$ on LinkedIn, the exchange with scientists at Researchgate. com, as well as personal exchanges with distinguished colleagues who stimulated our thinking all named individually earlier in publications - we thank each one. We further gratefully acknowledge the support of Marjan S. Rupnik, PhD, Professor of Physiology, Institute of Physiology, Center for Physiology and Pharmacology, Medical University of Vienna, Austria, for pre-submission review of the literature and our fruitful discussions.

\section{Conflict of interest}

The author reports the following conflict of interest: the attached figure was published within the Special Issue 
in: Chronic inflammation evoked by pathogenic stimulus during carcinogenesis - Special Issue: Disruption of homeostasis-induced signaling and crosstalk in the carcinogenesis paradigm "Epistemology of the origin of cancer". Due to its importance and understanding of the various signaling pathways and crosstalks, this figure needs to be re-published here as well.

Björn L.D.M. Brücher is Editor-in-Chief in Life Sciences-Medicine of 4open by EDP Sciences. Ijaz S. Jamall is Senior Editorial Board member in Life Sciences-Medicine of 4open by EDP Sciences. The authors, of their own initiative, suggested to the Managing Editorial to perform a transparent peer-review of their submittals. Neither author took any action to influence the standard submission and peer-review process, and report no conflict of interest. The authors alone are responsible for the content and writing of the manuscript of this Special Issue. This manuscript contains original material that has not previously been published. Both authors contributed to the discussion on its contents and approved the manuscript.

\section{References}

1. Stachura J, Heitzman J, Urbanczyk K (1999), Adenocarcinoma developes in the "cirrhotic" not just atrophic gastric mucosa. Pol J Pathol 50, 177-181.

2. Goo MJ, Ki MR, Lee HR, Yang HJ, Yuan DW, Hong IH, Park JK, Hong KS, Han JY, Hwang OK, Kim DH, Do SH, Cohn RD, Jeong K (2009), Helicobacter pylori promotes hepatic fibrosis in the animal model. Lab Invest 89, 1291-1303.

3. Ki MR, Goo MJ, Park JK, Hong IH, Ji AR, Han SY, You SY, Lee EM, Kim AY, Park SJ, Lee HJ, Kim SY, Jeong KS (2010), Helicobacter pylori accelerates hepatic fibrosis by sensitizing transforming growth factor- $\beta 1$-induced inflammatory signaling. Lab Invest 90, $1507-1516$.

4. Deenonpoe R, Mairiang E, Mairiang P, Pairojkul C, Chamgramol Y, Rinaldi G, Loukas A, Brindley PJ, Sripa B (2013), Elevated prevalence of Helicobacter species and virulence factors in opisthorchiasis and associated hepatobiliary disease. Sci Rep 7, 42744.

5. Sakr SA, Badrah GA, Sheir RA (2013), Histological and histochemical alterations in liver of chronic hepatitis $\mathrm{C}$ patients with Helicobacter pylori infection. Biomed Pharmacother 67, 367-374.

6. Gouveia MJ, Pakharukova MY, Laha T, Sripa B, Maksimova GA, Rinaldi G, Brindley PJ, Mordvinov VA, Amaro T, Santos LL, Costa JMCD, Vale N (2013), Infection with Opisthorchis felineus induces intraepithelial neoplasia of the biliary tract in a rodent model. Carcinogenesis 38, 929-937.

7. Jalouli J, Ibrahim SO, Mehrotra R, Jalouli MM, Sapkota D, Larsson PA, Hirsch JM (2010), Prevalence of viral (HPV, EBV, HSV) infections in oral submucous fibrosis and oral cancer from India. Acta Otolaryngol 130, 1306-1311.

8. Nayak MT, Singh A, Desai RS, Vanaki SS (2013), Immunohistochemical analysis of vimentin in oral submucous fibrosis. J Cancer Epidemiol 2013, 549041.

9. Feghali CA, Wright TM (1997), Cytokines in acute and chronic inflammation. Front Biosci 2, d12-26.
10. Gharaee-Kermani M, McCullumsmith RE, Charo IF, Kunkel SL, Phan SH (2003), CC-chemokine receptor 2 required for bleomycin-induced pulmonary fibrosis. Cytokine 24, 266-276.

11. Kendall RT, Feghali-Bostwick CA (2014), Fibroblasts in fibrosis: novel roles and mediators. Front Pharmacol 5, 123.

12. McKleroy W, Lee TH, Atabai K (2013), Always cleave up your mess: targeting collagen degradation to treat tissue fibrosis. Am J Physiol Lung Cell Mol Physiol 304, L709L721.

13. Cox TR, Bird D, Baker AM, Barker HE, Ho MW, Lang G, Erler (2013), LOX-mediated collagen crosslinking is responsible for fibrosis-enhanced metastasis. Cancer Res $73,1721-1732$

14. Wang T, Zhang L, Shi C, Sun H, Wang J, Li R, Zou Z, Ran X, Su Y (2012), TGF- $\beta$-induced miR-21 negatively regulates the antiproliferative activity but has no effect on EMT of TGF- $\beta$ in HaCaT cells. Int J Biochem Cell Biol $44,366-376$.

15. Bissell DM (1992), Lipocyte activation and hepatic fibrosis. Gastroenterology 102, 1803-1805.

16. Flavell SJ, Hou TZ, Lax S, Filer AD, Salmon M, Buckley CD (2008), Fibroblasts as novel therapeutic targets in chronic inflammation. Br J Pharmacol 153 Suppl, S241S246.

17. Okamura Y, Watari M, Jerud ES, Young DW, Ishizaka ST, Rose J, Chow JC, Strauss JF 3rd (2001), The extra domain A of fibronectin activates Toll-like receptor 4. J Biol Chem 276, 10229-10233.

18. Csordas G, Santra M, Reed CC, Eichstetter I, McQuillan DJ, Gross D, Nugent MA, Hajnoczky G, Iozzo RV (2000), Sustained down-regulation of the epidermal growth factor receptor by decorin. A mechanism for controlling tumor growth in vivo. J Biol Chem 275, 32879-32887.

19. Kresse H, Schönherr E (2001), Proteoglycans of the extracellular matrix and growth control. J Cell Physiol 189, 266-274.

20. Comalada M, Cardó M, Xaus J, Valledor AF, Lloberas J, Ventura F, Celada A (2003), Decorin reverses the repressive effect of autocrine-produced TGF-beta on mouse macrophage activation. J Immunol 170, 4450-4456.

21. Köninger J, Giese NA, Bartel M, di Mola FF, Berberat PO, di Sebastiano P, Giese T, Büchler MW, Friess H (2006), The ECM proteoglycan decorin links desmoplasia and inflammation in chronic pancreatitis. J Clin Pathol $59,21-27$

22. Kovalszky I, Nagy P, Szende B, Lapis K, Szalay F, Jeney A, Schaff Z (1998), Experimental and human liver fibrogenesis. Scand J Gastroenterol Suppl 228, 51-55.

23. Berk BC, Fujiwara K, Lehoux S (2007), ECM remodeling in hypertensive heart disease. J Clin Invest 117, 568-575.

24. Wang H, Fang R, Wang XF, Zhang F, Chen DY, Zhou B, Wang HS, Cai SH, Du J (2013), Stabilization of Snail through AKT/GSK-3 $\beta$ signaling pathway is required for TNF- $\alpha$-induced epithelial-mesenchymal transition in prostate cancer PC3 cells. Eur J Pharmacol 714, 48-55.

25. Lv L, Yuan J, Huang T, Zhang C, Zhu Z, Wang L, Jiang G, Zeng F (2014), Stabilization of Snail by HIF-1 $\alpha$ and TNF$\alpha$ is required for hypoxia-induced invasion in prostate cancer PC3 cells. Mol Biol Rep 41, 4573-4582.

26. Liu H, Xu L, He H, Zhu Y, Liu J, Wang S, Chen L, Wu Q, $\mathrm{Xu}$ J, Gu J (2012), Hepatitis B virus X protein promotes hepatoma cell invasion and metastasis by stabilizing Snail protein. Cancer Sci 103, 2072-2081. 
27. Campbell SE, Katwa LC (1997), Angiotensin II stimulated expression of transforming growth factor-beta1 in cardiac fibroblasts and myofibroblasts. J Mol Cell Cardiol 29, 1947-1958.

28. Wang H, Wang HS, Zhou BH, Li CL, Zhang F, Wang XF, Zhang G, Bu XZ, Cai SH, Du J (2013), Epithelialmesenchymal transition (EMT) induced by TNF- $\alpha$ requires $\mathrm{AKT} / \mathrm{GSK}-3 \beta$-mediated stabilization of snail in colorectal cancer. PLoS ONE 8, e56664.

29. Hofmann C, Dunger N, Schölmerich J, Falk W, Obermeier F (2010), Glycogen synthase kinase $3-\beta$ : a master regulator of toll-like receptor-mediated chronic intestinal inflammation. Inflamm Bowel Dis 16, 1850-1858.

30. Thiel A, Heinonen M, Rintahaka J, Hallikainen T, Hemmes A, Dixon DA, Haglund C, Ristimäki A (2006), Expression of cyclooxygenase-2 is regulated by glycogen synthase kinase-3beta in gastric cancer cells. J Biol Chem 281, 4564-4569.

31. Ding L, Liou GY, Schmitt DM, Storz P, Zhang JS, Billadeau DD (2013), Glycogen synthase kinase-3 $\beta$ ablation limits pancreatitis-induced acinar-to-ductal metaplasia. J Pathol 243, 65-77.

32. Park H, Lee M, Kim DW, Hong SY, Lee H (2016), Glycogen synthase kinase $3 \beta$ and cyclin D1 expression in cervical carcinogenesis. Obstet Gynecol Sci 59, 470-478.

33. Di Gregorio J, Sferra R, Speca S, Vetuschi A, Dubuquoy C, Desreumaux P, Pompili S, Cristiano L, Gaudio E, Flati V, Latella G (2013), Role of glycogen synthase kinase-3 $\beta$ and PPAR- $\gamma$ on epithelial-to-mesenchymal transition in DSS-induced colorectal fibrosis, PLoS ONE 12, e0171093.

34. Son YO, Pratheeshkumar P, Wang L, Wang X, Fan J, Kim DH, Lee JY, Zhang Z, Lee JC, Shi X (2013), Reactive oxygen species mediate $\mathrm{Cr}(\mathrm{VI})$-induced carcinogenesis through PI3K/AKT-dependent activation of GSK-3 $\beta$ / $\beta$-catenin signaling. Toxicol Appl Pharmacol 271, 239-248.

35. Zumbrunn J, Kinoshita K, Hyman AA, Näthke IS (2001), Binding of the adenomatous polyposis coli protein to microtubules increases microtubule stability and is regulated by GSK3 beta phosphorylation. Curr Biol 11, $44-49$.

36. Jiang H, Hegde S, Knolhoff BL, Zhu Y, Herndon JM, Meyer MA, Nywening TM, Hawkins WG, Shapiro IM, Weaver DT, Pachter JA, Wang-Gillam A, DeNardo DG (2016), Targeting focal adhesion kinase renders pancreatic cancers responsive to checkpoint immunotherapy. Nat Med 22, 851-860.

37. Grimm S, Jennek S, Singh R, Enkelmann A, Junker K, Rippaus N, Berndt A, Friedrich K (2015), Malignancy of bladder cancer cells is enhanced by tumor-associated fibroblasts through a multifaceted cytokine-chemokine loop. Exp Cell Res 335, 1-11.

38. Kuhn C, McDonald JA (1991), The roles of the myofibroblast in idiopathic pulmonary fibrosis. Ultrastructural and immunohistochemical features of sites of active extracellular matrix synthesis. Am J Pathol 138, $1257-1265$.

39. Gross TJ, Hunninghake GW (2001), Idiopathic pulmonary fibrosis. N Engl J Med 345, 517-525.

40. Tomasek JJ, Gabbiani G, Hinz B, Chaponnier C, Brown RA (2002), Myofibroblasts and mechano-regulation of connective tissue remodeling. Nat Rev Mol Cell Biol 3, 349-363.

41. Liu F, Mih JD, Shea BS, Kho AT, Sharif AS, Tager AM, Tschumperlin DJ (2010), Feedback amplification of fibrosis through matrix stiffening and COX-2 suppression. J Cell Biol 190, 693-706.

42. Vyalov SL, Gabbiani G, Kapanci Y (1993), Rat alveolar myofibroblasts acquire alpha-smooth muscle actin expression during bleomycin-induced pulmonary fibrosis. Am J Pathol 143, 1754-1765.

43. Desmouliere A, Geinoz A, Gabbiani F, Gabbiani G (1993), Transforming growth factor-13l induces a-smooth muscle actin expression in granulation tissue myofibroblasts and in quiescent and growing cultured fibroblasts. J Cell Biol $122,103-111$.

44. Huang CP, Cheng CM, Su HL, Lin YW (2015), Syndecan4 promotes epithelial tumor cells spreading and regulates the turnover of PKC $\alpha$ activity under mechanical stimulation on the elastomeric substrates. Cell Physiol Biochem $36,1291-1304$

45. Richards KE, Zeleniak AE, Fishel ML, Wu J, Littlepage LE, Hill R (2013), Cancer-associated fibroblast exosomes regulate survival and proliferation of pancreatic cancer cells. Oncogene 36, 1770-1778.

46. Lee SK, Choi MY, Bae SY, Lee JH, Lee HC, Kil WH, Lee JE, Kim SW, Nam SJ (2015), Immediate postoperative inflammation is an important prognostic factor in breast cancer. Oncology 88, 337-344.

47. Yoshida K, Murata M, Yamaguchi T, Matsuzaki K (2014), TGF- $\beta$ /Smad signaling during hepatic fibrocarcinogenesis (review). Int J Oncol 45, 1363-1371.

48. Saha A, Jha HC, Upadhyay SK, Robertson ES (2015), Epigenetic silencing of tumor suppressor genes during in vitro Epstein-Barr virus infection. Proc Natl Acad Sci USA 112, E5199-E5207.

49. Massague J, Wotton D (2000), Transcriptional control by the TGF-beta/Smad signaling system. EMBO J 19, 17451754 .

50. Roberts AB, Wakefield LM (2003), The two faces of transforming growth factor beta in carcinogenesis. Proc Natl Acad Sci USA 100, 8621-8623.

51. Benson JR (2004), Role of transforming growth factor beta in breast carcinogenesis. Lancet Oncol 5, 229-239.

52. Javelaud D, Mauviel A (2004), Mammalian transforming growth factor-betas: Smad signaling and physio-pathological roles. Int J Biochem Cell Biol 36, 1161-1165.

53. Pühringer-Oppermann F, Sarbia M, Ott N, Brücher BLDM (2010), The predictive value of genes of the TGFbeta1 pathway in multimodally treated squamous cell carcinoma of the esophagus. Int J Colorectal Dis 25, $515-521$.

54. Calon A, Lonardo E, Berenguer-Llergo A, Espinet E, Hernando-Momblona X, Iglesias M, Sevillano M, PalomoPonce S, Tauriello DV, Byrom D, Cortina C, Morral C, Barceló C, Tosi S, Riera A, Attolini CS, Rossell D, Sancho E, Batlle E (2015), Stromal gene expression defines poorprognosis subtypes in colorectal cancer. Nat Genet 47, 320-329.

55. Voorhees PM, Orlowski RZ (2006), The proteasome and proteasome inhibitors in cancer therapy. Annu Rev Pharmacol Toxicol 46, 189-213.

56. Luo K (2004), Ski and SnoN: negative regulators of TGFbeta signaling. Curr Opin Genet Dev 14, 65-70.

57. Deheuninck J, Luo K (2009), Ski and SnoN, potent negative regulators of TGF-beta signaling. Cell Res 19, 47-57.

58. Chen CR, Kang Y, Massague J (2001), Defective repression of c-myc in breast cancer cells: a loss at the core of the transforming growth factor beta growth arrest program. Proc Natl Acad Sci USA 98, 992-999.

59. Miyazono K, Maeda S, Imamura T (2004), Coordinate regulation of cell growth and differentiation by TGF- 
beta superfamily and Runx proteins. Oncogene 23, 4232-4237.

60. Frederick JP, Liberati NT, Waddell DS, Shi Y, Wang XF (2004), Transforming growth factor beta-mediated transcriptional repression of c-myc is dependent on direct binding of Smad3 to a novel repressive Smad binding element. Mol Cell Biol 24, 2546-2559.

61. Matsuura I, Denissova NG, Wang G, He D, Long J, Liu F (2004), Cyclin-dependent kinases regulate the antiproliferative function of Smads. Nature 430, 226-231.

62. Dai C, Yang J, Liu Y (2003), Transforming growth factorbeta1 potentiates renal tubular epithelial cell death by a mechanism independent of Smad signaling. J Biol Chem 278, 12537-12545.

63. Edlund S, Bu S, Schuster N, Aspenström P, Heuchel R, Heldin NE, ten Dijke P, Heldin CH, Landström M (2003), Transforming growth factor-beta1 (TGF-beta)-induced apoptosis of prostate cancer cells involves Smad7dependent activation of p38 by TGF-beta-activated kinase 1 and mitogen-activated protein kinase kinase 3 . Mol Biol Cell 14, 529-544.

64. Yoo J, Ghiassi M, Jirmanova L, Balliet AG, Hoffman B, Fornace AJ Jr, Liebermann DA, Bottinger EP, Roberts AB (2003), Transforming growth factor-beta-induced apoptosis is mediated by Smad-dependent expression of GADD45b through p38 activation. J Biol Chem 278, 43001-43007.

65. Kim KY, Kim BC, Xu Z, Kim SJ (2004), Mixed lineage kinase 3 (MLK3)-activated p38 MAP kinase mediates transforming growth factor-beta-induced apoptosis in hepatoma cells. J Biol Chem 279, 29478-29484.

66. Landström M, Heldin NE, Bu S, Hermansson A, Itoh S, ten Dijke P, Heldin CH (2000), Smad7 mediates apoptosis induced by transforming growth factor beta in prostatic carcinoma cells. Curr Biol 10, 535-538.

67. Mazars A, Lallemand F, Prunier C, Marais J, Ferrand N, Pessah M, Cherqui G, Atfi A (2001), Evidence for a role of the JNK cascade in Smad7-mediated apoptosis. J Biol Chem 276, 36797-36803.

68. Townsend DM, Tew KD (2003), The role of glutathione-Stransferase in anti-cancer drug resistance. Oncogene 22, 7369-7375.

69. Cullen KJ, Newkirk KA, Schumaker LM, Aldosari N, Rone JD, Haddad BR (2003), Glutathione S-transferase pi amplification is associated with cisplatin resistance in head and neck squamous cell carcinoma cell lines and primary tumors. Cancer Res 63, 8097-9102.

70. Kim SI, Kwak JH, Na HJ, Kim JK, Ding Y, Choi ME (2009), Transforming growth factor-beta (TGFbeta1) activates TAK1 via TAB1-mediated autophosphorylation, independent of TGF-beta receptor kinase activity in mesangial cells. J Biol Chem 284, 2228522296.

71. Caraci F, Gili E, Calafiore M, Failla M, La Rosa C, Crimi N, Sortino MA, Nicoletti F, Copani A, Vancheri C (2008), TGF-beta1 targets the GSK-3beta/beta-catenin pathway via ERK activation in the transition of human lung fibroblasts into myofibroblasts. Pharmacol Res 57, 274-282.

72. Miettinen PJ, Ebner R, Lopez AR, Derynck R (1994), TGF-beta induced transdifferentiation of mammary epithelial cells to mesenchymal cells: involvement of type I receptors. J Cell Biol 127, 2021-2036.

73. Kim S, Lee J, Jeon M, Nam SJ, Lee JE (2015), Elevated TGF- $\beta 1$ and $-\beta 2$ expression accelerates the epithelial to mesenchymal transition in triple-negative breast cancer cells. Cytokine 75, 151-158.
74. Cho HJ, Baek KE, Saika S, Jeong MJ, Yoo J (2007), Snail is required for transforming growth factor-beta-induced epithelial-mesenchymal transition by activating PI3 kinase/Akt signal pathway. Biochem Biophys Res Commun 353, 337-343.

75. Wettstein G, Bellaye PS, Kolb M, Hammann A, Crestani B, Soler P, Marchal-Somme J, Hazoume A, Gauldie J, Gunther A, Micheau O, Gleave M, Camus P, Garrido C, Bonniaud P (2013), Inhibition of HSP27 blocks fibrosis development and EMT features by promoting Snail degradation. FASEB J 27, 1549-1560.

76. Wang H, Fang R, Wang XF, Zhang F, Chen DY, Zhou B, Wang HS, Cai SH, Du J (2013), Stabilization of Snail through AKT/GSK-3 $\beta$ signaling pathway is required for TNF- $\alpha$-induced epithelial-mesenchymal transition in prostate cancer PC3 cells. Eur J Pharmacol 714, 48-55.

77. Bae GY, Hong SK, Park JR, Kwon OS, Kim KT, Koo J, Oh E, Cha HJ (2016), Chronic TGFß stimulation promotes the metastatic potential of lung cancer cells by Snail protein stabilization through integrin $\beta 3$-AktGSK3 $\beta$ signaling. Oncotarget 7, 25366-25376.

78. Palumbo-Zerr K, Zerr P, Distler A, Fliehr J, Mancuso R, Huang J, Mielenz D, Tomcik M, Fürnrohr BG, Scholtysek C, Dees C, Beyer C, Krönke G, Metzger D, Distler O, Schett G, Distler JH (2015), Orphan nuclear receptor NR4A1 regulates transforming growth factor- $\beta$ signaling and fibrosis. Nat Med 21, 150-158.

79. Zhou F, Drabsch Y, Dekker TJ, de Vinuesa AG, Li Y, Hawinkels LJ, Sheppard KA, Goumans MJ, Luwor RB, de Vries CJ, Mesker WE, Tollenaar RA, Devilee P, Lu CX, Zhu H, Zhang L, Dijke PT (2014), Nuclear receptor NR4A1 promotes breast cancer invasion and metastasis by activating TGF- $\beta$ signaling. Nat Commun 5,3388 .

80. Tan Y, Li Y (2015), HCV core protein promotes hepatocyte proliferation and chemoresistance by inhibiting NR4A1. Biochem Biophys Res Commun 466, 592-598.

81. de Léséleuc L, Denis F (2006), Inhibition of apoptosis by Nur77 through NF-kappaB activity modulation. Cell Death Differ 13, 293-300.

82. Peinado H, Olmeda D, Cano A (2007), Snail, Zeb and bHLH factors in tumour progression: an alliance against the epithelial phenotype? Nat Rev Cancer 7, 415-428.

83. Taylor MA, Amin JD, Kirschmann DA, Schiemann WP (2011), Lysyl oxidase contributes to mechanotransduction-mediated regulation of transforming growth factor- $\beta$ signaling in breast cancer cells. Neoplasia 13, 406-418.

84. Moon HJ, Finney J, Xu L, Moore D, Welch DR, Mure M (2013), MCF-7 cells expressing nuclear associated lysyl oxidase-like 2 (LOXL2) exhibit an epithelial-to-mesenchymal transition (EMT) phenotype and are highly invasive in vitro. J Biol Chem 288, 30000-30008.

85. Park PG, Jo SJ, Kim MJ, Kim HJ, Lee JH, Park CK, Kim H, Lee KY, Kim H, Park JH, Dong SM, Lee JM (2013), Role of LOXL2 in the epithelial-mesenchymal transition and colorectal cancer metastasis. Oncotarget 8, 8032580335.

86. Boak AM, Roy R, Berk J, Taylor L, Polgar P, Goldstein RH, Kagan HM (1994), Regulation of lysyl oxidase expression in lung fibroblasts by transforming growth factor-beta 1 and prostaglandin E2. Am J Respir Cell Mol Biol 11, 751-755.

87. Choung J, Taylor L, Thomas K, Zhou X, Kagan H, Yang X, Polgar P (1998), Role of EP2 receptors and cAMP in prostaglandin E2 regulated expression of type I collagen alpha1, lysyl oxidase, and cyclooxygenase-1 genes in human embryo lung fibroblasts. J Cell Biochem 71, 254-263. 
88. Budhu S, Schaer DA, Li Y, Toledo-Crow R, Panageas K, Yang X, Zhong H, Houghton AN, Silverstein SC, Merghoub T, Wolchok JD (2013), Blockade of surfacebound TGF- $\beta$ on regulatory T cells abrogates suppression of effector $\mathrm{T}$ cell function in the tumor microenvironment. Sci Signal 10, pii: eaak9702.

89. von Rahden BHA, Brücher BLDM, Langner C, Hartl S, Theisen J, Siewert JR, Stein HJ, Sarbia M (2006), Expression of COX-1 and 2, mPGES and TGF-Beta1 and their link with proangiogenetic factors VEGF-A and VEGF-A C in Primary Adenocarcinomas of the Small Intestine. Br J Surg 93, 1424-1432.

90. Möbius C, Freire J, Becker I, Feith M, Brücher BLDM, Hennig M, Siewert JR, Stein HJ (2007), VEGF-C expression in squamous cell carcinoma and adenocarcinoma of the esophagus. World J Surg 31, 1768-1772.

91. Hurst V IV, Goldberg PL, Minnear FL, Heimark RL, Vincent PA (1999), Rearrangement of adherens junctions by transforming growth factor-beta1: role of contraction. Am J Physiol 276, L582-L595.

92. Gaide Chevronnay HP, Selvais C, Emonard H, Galant C, Marbaix E, Henriet P (2012), Regulation of matrix metalloproteinases activity studied in human endometrium as a paradigm of cyclic tissue breakdown and regeneration. Biochim Biophys Acta 1824, $146-156$.

93. Zheng G, Lyons JG, Tan TK, Wang Y, Hsu TT, Min D, Succar L, Rangan GK, Hu M, Henderson BR, Alexander SI, Harris DC (2009), Disruption of E-cadherin by matrix metalloproteinase directly mediates epithelial-mesenchymal transition downstream of transforming growth factorbeta1 in renal tubular epithelial cells. Am J Pathol 175, 580-591.

94. Wells A, Yates C, Shepard CR (2008), E-cadherin as an indicator of mesenchymal to epithelial reverting transitions during the metastatic seeding of disseminated carcinomas. Clin Exp Metastasis 25, 621-628.

95. Duangkumpha K, Techasen A, Loilome W, Namwat N, Thanan R, Khuntikeo N, Yongvanit P (2014), BMP-7 blocks the effects of TGF-beta-induced EMT in cholangiocarcinoma. Tumour Biol 35, 9667-9676.

96. Shi L, Dong N, Fang X, Wang X (2016), Regulatory mechanisms of TGF- $\beta 1$-induced fibrogenesis of human alveolar epithelial cells. J Cell Mol Med 20, 2183-2193.

97. Hamidi A, Song J, Thakur N, Itoh S, Marcusson A, Bergh A, Heldin CH, Landström M (2013), TGF- $\beta$ promotes PI3K-AKT signaling and prostate cancer cell migration through the TRAF6-mediated ubiquitylation of $\mathrm{p} 85 \alpha$. Sci Signal 10, pii:eaal 4186.

98. Bradham DM, Igarashi A, Potter RL, Grotendorst GR (1991), Connective tissue growth factor: a cysteine-rich mitogen secreted by human vascular endothelial cells is related to the $\mathrm{SRC}$-induced immediate early gene product CEF-10. J Cell Biol 114, 1285-1294.

99. Lipson KE, Wong C, Teng Y, Spong S (2012), CTGF is a central mediator of tissue remodeling and fibrosis and its inhibition can reverse the process of fibrosis. Fibrogenesis Tissue Repair 5, S24.

100. Pez F, Dayan F, Durivault J, Kaniewski B, Aimond G, Le Provost GS, Deux B, Clézardin P, Sommer P, Pouysségur J, Reynaud C (2011), The HIF-1-inducible lysyl oxidase activates HIF-1 via the Akt pathway in a positive regulation loop and synergizes with HIF-1 in promoting tumor cell growth. Cancer Res 71, 1647-1657.

101. Xie J, Wang C, Huang DY, Zhang Y, Xu J, Kolesnikov SS, Sung KL, Zhao H (2013), TGF-beta1 induces the different expressions of lysyl oxidases and matrix metalloproteinases in anterior cruciate ligament and medial collateral ligament fibroblasts after mechanical injury. J Biomech 46, 890-898.

102. Brücher BLDM, Jamall IS (2014), Epistemology of the origin of cancer: a new paradigm. BMC Cancer 14, 1-15.

103. Brücher BLDM, Jamall IS (2014), Cell-cell communication in tumor microenvironment, carcinogenesis and anticancer treatment. Cell Physiol Biochem 34, 213-243.

104. Dibble CC, Cantley LC (2015), Regulation of mTORC1 by PI3K signaling. Trends Cell Biol 25, 545-555.

105. Sabers CJ, Martin MM, Brunn GJ, Williams JM, Dumont FJ, Wiederrecht G, Abraham RT (1995), Isolation of a protein target of the FKBP12-rapamycin complex in mammalian cells. J Biol Chem 270, 815-822.

106. Guertin DA, Sabatini DM (2005), An expanding role for mTOR in cancer. Trends Mol Med 11, 353-361.

107. Sarbassov DD, Ali SM, Sabatini DM (2005), Growing roles for the mTOR pathway. Curr Opin Cell Biol 17, 596603.

108. Yen CJ, Lin YJ, Yen CS, Tsai HW, Tsai TF, Chang KY, Huang WC, Lin PW, Chiang CW, Chang TT (2012), Hepatitis B virus X protein upregulates mTOR signaling through IKK $\beta$ to increase cell proliferation and VEGF production in hepatocellular carcinoma. PLoS ONE 7, e41931.

109. Lee DF, Kuo HP, Chen CT, Hsu JM, Chou CK, Wei Y, Sun HL, Li LY, Ping B, Huang WC, He X, Hung JY, Lai CC, Ding Q, Su JL, Yang JY, Sahin AA, Hortobagyi GN, Tsai FJ, Tsai CH, Hung MC (2007), IKK beta suppression of TSC1 links inflammation and tumor angiogenesis via the mTOR pathway. Cell 130, 440-455.

110. Schlessinger K, Hall A (2004), GSK-3beta sets Snail's pace. Nat Cell Biol 6, 913-915.

111. Peinado H, Quintanilla M, Cano A (2003), Transforming growth factor beta-1 induces snail transcription factor in epithelial cell lines: mechanisms for epithelial mesenchymal transitions. J Biol Chem 278, 21113-21123.

112. Breasson L, Becattini B, Sardi C, Molinaro A, Zani F, Marone R, Botindari F, Bousquenaud M, Ruegg C, Wymann MP, Solinas G (2013), PI3K $\gamma$ activity in leukocytes promotes adipose tissue inflammation and early-onset insulin resistance during obesity. Sci Signal 10, eaaf2969.

113. Santo EE, Stroeken P, Sluis PV, Koster J, Versteeg R, Westerhout EM (2013), FOXO3a is a major target of inactivation by $\mathrm{PI} 3 \mathrm{~K} / \mathrm{AKT}$ signaling in aggressive neuroblastoma. Cancer Res 73, 2189-2198.

114. Min M, Yang J, Yang YS, Liu Y, Liu LM, Xu Y (2015), Expression of transcription factor FOXO3a is decreased in patients with ulcerative colitis. Chin Med J (Engl) 128, 2759-2763.

115. Hu MC, Lee DF, Xia W, Golfman LS, Ou-Yang F, Yang JY, Zou Y, Bao S, Hanada N, Saso H, Kobayashi R, Hung MC (2004), IkB kinase promotes tumorigenesis through inhibition of forkhead FOXO3a. Cell 117, 225-237. Erratum in: Cell 2007, 129, 1427-1428.

116. Yang XB, Zhao JJ, Huang CY, Wang QJ, Pan K, Wang DD, Pan QZ, Jiang SS, Lv L, Gao X, Chen HW, Yao JY, Zhi M, Xia JC (2013), Decreased expression of the FOXO3a gene is associated with poor prognosis in primary gastric adenocarcinoma patients. PLoS ONE 8 , e78158.

117. Yu S, Yu Y, Sun Y, Wang X, Luo R, Zhao N, Zhang W, Li Q, Cui Y, Wang Y, Li W, Liu T (2015), Activation of FOXO3a suggests good prognosis of patients with 
radically resected gastric cancer. Int J Clin Exp Pathol 8, 2963-2970.

118. Yang LL, Wang XY, Zheng LY, Fang SJ, Xu M, Zhao ZW, Ji JS (2013), The role of FOXO3a-Bim signaling in triptolide induced bladder cancer T24 cells apoptosis. Zhonghua Yi Xue Za Zhi 97, 1187-1190.

119. Birkenkamp KU, Coffer PJ (2003), Regulation of cell survival and proliferation by the FOXO (Forkhead box, class O) subfamily of Forkhead transcription factors. Biochem Soc Trans 31, 292-297.

120. Yang JY, Zong CS, Xia W, Yamaguchi H, Ding Q, Xie X, Lang JY, Lai CC, Chang CJ, Huang WC, Huang H, Kuo HP, Lee DF, Li LY, Lien HC, Cheng X, Chang KJ, Hsiao CD, Tsai FJ, Tsai CH, Sahin AA, Muller WJ, Mills GB, Yu D, Hortobagyi GN, Hung MC (2008), ERK promotes tumorigenesis by inhibiting FOXO3a via MDM2-mediated degradation. Nat Cell Biol 10, 138-148.

121. Erlacher M, Michalak EM, Kelly PN, Labi V, Niederegger H, Coultas L, Adams JM, Strasser A, Villunger A (2005), BH3-only proteins Puma and Bim are rate-limiting for gamma-radiation- and glucocorticoid-induced apoptosis of lymphoid cells in vivo. Blood 106, 4131-4138.

122. Ekoff M, Kaufmann T, Engström M, Motoyama N, Villunger A, Jönsson JI, Strasser A, Nilsson G (2007), The BH3-only protein Puma plays an essential role in cytokine deprivation induced apoptosis of mast cells. Blood 110, 3209-3217.

123. You H, Pellegrini M, Tsuchihara K, Yamamoto K, Hacker G, Erlacher M, Villunger A, Mak TW (2006), FOXO3a-dependent regulation of Puma in response to cytokine/growth factor withdrawal. J Exp Med 203, 1657-1663.

124. Chen CR, Kang Y, Siegel PM, Massagué J (2002), E2F4/5 and p107 as Smad cofactors linking the TGFbeta receptor to c-myc repression. Cell 110, 19-32.

125. Soucek L, Whitfield J, Martins CP, Finch AJ, Murphy DJ, Sodir NM, Karnezis AN, Swigart LB, Nasi S, Evan GI (2008), Modelling Myc inhibition as a cancer therapy. Nature 455, 679-683.

126. Ohtani N, Brennan P, Gaubatz S, Sanij E, Hertzog P, Wolvetang E, Ghysdael J, Rowe M, Hara E (2003), Epstein-Barr virus LMP1 blocks p16INK4a-RB pathway by promoting nuclear export of E2F4/5. J Cell Biol 162, 173-183.

127. Ewen ME, Xing YG, Lawrence JB and Livingston DM (1991), Molecular cloning, chromosomal mapping, and expression of the cDNA for p107, a retinoblastoma gene product-related protein. Cell 66, 1155-1164.

128. Baldi A, Esposito V, De Luca A, Fu Y, Meoli I, Giordano GG, Caputi M, Baldi F, Giordano A (1997), Differential expression of $\mathrm{Rb} 2 / \mathrm{p} 130$ and p107 in normal human tissues and in primary lung cancer. Clin Cancer Res 3, 1691-1697.

129. Ikeda MA, Jakoi L, Nevins JR (1996), A unique role for the $\mathrm{Rb}$ protein in controlling E2F accumulation during cell growth and differentiation. Proc Natl Acad Sci USA 93, 3215-3220.

130. Xiao ZX, Ginsberg D, Ewen M, Livingston DM (1996), Regulation of the retinoblastoma protein-related protein p107 by G1 cyclin-associated kinases. Proc Natl Acad Sci USA 93, 4633-4637.

131. Rodier G, Makris C, Coulombe P, Scime A, Nakayama K, Nakayama KI, Meloche S (2005), p107 inhibits G1 to S phase progression by down-regulating expression of the F-box protein Skp2. J Cell Biol 168, 55-66.

132. Johnson BR, Nitta RT, Frock RL, Mounkes L, Barbie DA, Stewart CL, Harlow E, Kennedy BK (2004), A-type lamins regulate retinoblastoma protein function by promoting subnuclear localization and preventing proteasomal degradation. Proc Natl Acad Sci USA 101, 96779682.

133. Parakati R, DiMario JX (2005), Dynamic transcriptional regulatory complexes, including E2F4, p107, p130, and Sp1, control fibroblast growth factor receptor 1 gene expression during myogenesis. J Biol Chem 280, 21284-21294.

134. Wu F, Li JQ, Miki H, Nishioka M, Fujita J, Ohmori M, Imaida K, Kuriyama S (2002), p107 Expression in colorectal tumours rises during carcinogenesis and falls during invasion. Eur J Cancer 38, 1838-1848.

135. Russo G, Zamparelli A, Howard CM, Minimo C, Bellan C, Carillo G, Califano L, Leoncini L, Giordano A, Claudio PP (2005), Expression of cell cycle-regulated proteins pRB2/ p130, p107, E2F4, p27, and pCNA in salivary gland tumors: prognostic and diagnostic implications. Clin Cancer Res 11, 3265-3273.

136. Shin MK, Pitot HC, Lambert PF (2012), Pocket proteins suppress head and neck cancer. Cancer Res $72,1280-1289$.

137. Tanaka N, Odajima T, Nakano T, Kimijima Y, Yamada S, Ogi K, Kohama G (1999), Immunohistochemical investigation of new suppressor oncogene p130 in oral squamous cell carcinoma. Oral Oncol 35, 321-325.

138. Claudio PP (2000), Immunohistochemical investigation of new suppressor oncogene p130 in oral squamous cell carcinoma. Oral Oncol 35, 321-325.

139. Milde-Langosch K, Goemann C, Methner C, Rieck G, Bamberger AM, Löning T (2001), Expression of Rb2/p130 in breast and endometrial cancer: correlations with hormone receptor status. Br J Cancer 85, 546-551.

140. Baldi A, Esposito V, De Luca A, Howard CM, Mazzarella G, Baldi F, Caputi M, Giordano A (1996), Differential expression of the retinoblastoma gene family members $\mathrm{pRb} / \mathrm{p} 105, \mathrm{p} 107$, and $\mathrm{pRb} 2 / \mathrm{p} 130$ in lung cancer. Clin Cancer Res 2, 1239-1245.

141. Claudio PP, Howard CM, Baldi A, De Luca A, Fu Y, Condorelli G, Sun Y, Colburn N, Calabretta B, Giordano A (1994), p130/pRb2 has growth suppressive properties similar to yet distinctive from those of retinoblastoma family members $\mathrm{pRb}$ and $\mathrm{p} 107$. Cancer Res 54, 5556-5560.

142. Cinti C, Claudio PP, Howard CM, Neri LM, Fu Y, Leoncini L, Tosi GM, Maraldi NM, Giordano A (2000), Genetic alterations disrupting the nuclear localization of the retinoblastoma related gene $\mathrm{RB} 2 / \mathrm{p} 130$ in human tumor cell lines and primary tumors. Cancer Res 60, 383389.

143. Susini T, Baldi F, Howard CM, Baldi A, Taddei G, Massi D, Rapi S, Savino L, Massi G, Giordano A (1998), Expression of the retinoblastoma-related gene Rb2/p130 correlates with clinical outcome in endometrial cancer. J Clin Oncol 16, 1085-1093.

144. Claudio PP, Russo G, Kumar CA, Minimo C, Farina A, Tutton S, Nuzzo G, Giuliante F, Angeloni G, Maria V, Vecchio FM, Campli CD, Giordano A (2004), pRb2/p130, vascular endothelial growth factor, p27(KIP1), and proliferating cell nuclear antigen expression in hepatocellular carcinoma: their clinical significance. Clin Cancer Res 10, 3509-3517.

145. Russo G, Zamparelli A, Howard CM, Minimo C, Bellan C, Carillo G, Califano L, Leoncini L, Giordano A, Claudio PP (2005), Expression of cell cycle-regulated proteins pRB2/ p130, p107, E2F4, p27, and pCNA in salivary gland tumors: prognostic and diagnostic implications. Clin Cancer Res 11, 3265-3273. 
146. Woessner JF Jr (1962), Catabolism of collagen and noncollagen protein in the rat uterus during post-partum involution. Biochem J 83, 304-314.

147. Iyer RP, Patterson NL, Fields GB, Lindsey ML (2012), The history of matrix metalloproteinases: milestones, myths, and misperceptions. Am J Physiol Heart Circ Physiol 303, H919-H930.

148. Gross J, Lapiere CM (1962), Collagenolytic activity in amphibian tissues: a tissue culture assay. Proc Natl Acad Sci USA 48, 1014-1022.

149. Nagai Y, Lapiere CM, Gross J (1966), Tadpole collagenase. Preparation and purification. Biochemistry 5, 31233130.

150. Verma RP, Hansch C (2007), Matrix metalloproteinases (MMPs): chemical-biological functions and (Q)SARs. Bioorg Med Chem 15, 2223-2268.

151. Urso ML, Wang R, Zambraski EJ, Liang (2012), Adenosine A3 receptor stimulation reduces muscle injury following physical trauma and is associated with alterations in the MMP/TIMP response. J Appl Physiol 112, 658-670.

152. Overall CM, Lopez-Otin C (2002), Strategies for MMP inhibition in cancer: innovations for the post-trial era. Nat Rev Cancer 2, 657-672.

153. Overall CM, Kleifeld O (2006), Tumour microenvironment - opinion: validating matrix metalloproteinases as drug targets and anti-targets for cancer therapy. Nat Rev Cancer 6, 227-239.

154. Olson MW, Gervasi DC, Mobashery S, Fridman R (1997), Kinetic analysis of the binding of human matrix metalloproteinase- 2 and -9 to tissue inhibitor of metalloproteinase (TIMP)-1 and TIMP-2. J Biol Chem 272, 2997529983.

155. Price B, Dennison C, Tschesche H, Elliott E (2000), Neutrophil tissue inhibitor of matrix metalloprotetinases1 occurs in novel vesicles that do not fuse with the phagosome. J Biol Chem 275, 28308-28315.

156. Gerg M, Kopitz C, Schaten S, Tschukes S, Bandapalli OR, Stangl M, Hann von Weyhern CW, Brücher BLDM, Edwards DR, Brand K, Krüger A (2008), Distinct functionality of tumor cell-derived gelatinases during formation of liver metastases. Mol Cancer 6, $341-351$.

157. Kopitz C, Gerg M, Bandapalli OR, Ister D, Pennington CJ, Hauser S, Flechsig C, Krell HW, Antolovic D, Brew K, Nagase H, Stangl M, von Weyhern CW, Brücher BLDM, Brand K, Coussens LM, Edwards DR, Krüger A (2007), Tissue inhibitor of metalloproteinases-1 promotes liver metastasis by induction of hepatocyte growth factor signaling. Cancer Res 67, 8615-8623.

158. Elieh Ali Komi D, Grauwet K (2013), Role of mast cells in regulation of $\mathrm{T}$ cell responses in experimental and clinical settings. Clin Rev Allergy Immunol. DOI: 10.1007/ s12016-017-8646-z

159. Deimann W (1984), Endogenous peroxidase activity in mononuclear phagocytes. Prog Histochem Cytochem 15, $1-58$.

160. Galli SJ, Borregaard N, Wynn TA (2011), Phenotypic and functional plasticity of cells of innate immunity: macrophages, mast cells and neutrophils. Nat Immunol 12, 1035-1044.

161. Nourshargh S, Alon R (2014), Leukocyte migration into inflamed tissues. Immunity 41, 694-707.

162. Wang J, Hossain M, Thanabalasuriar A, Gunzer M, Meininger C, Kubes P (2013), Visualizing the function and fate of neutrophils in sterile injury and repair. Science 358, $111-116$
163. Zieker D, Königsrainer I, Tritschler I, Löffler M, Beckert S, Traub F, Nieselt K, Bühler S, Weller M, Gaeddcke J, Taichman RS, Northoff H, Brücher BLDM, Königsrainer A (2010), P Phosphoglycerate Kinase1 a promoting enzyme for peritoneal dissemination in gastric cancer. Int J Cancer 126, 1513-1520.

164. Zieker D, Königsrainer I, Weinreich J, Beckert S, Glatzle J, Nieselt K, Bühler S, Löffler M, Gaedcke J, Northoff H, Manheim JG, Wiehr S, Pichler PJ, von-Weyhern C, Brücher BLDM, Königsrainer A (2010), Phosphoglycerate Kinase 1 promoting tumor progression and metastasis in gastric cancer - detected in a tumour mouse model using positron emission tomography/magnetic resosonance imaging. Cell Physiol Biochem 26, 147-154.

165. Xie H, Tong G, Zhang Y, Liang S, Tang K, Yang Q (2013), PGK1 drives hepatocellular carcinoma metastasis by enhancing metabolic process. Int J Mol Sci 18, pii: E1630.

166. Wald O, Pappo O, Safadi R, Dagan-Berger M, Beider K, Wald H, Franitza S, Weiss I, Avniel S, Boaz P, Hanna J, Zamir G, Eid A, Mandelboim O, Spengler U, Galun E, Peled A (2004), Involvement of the CXCL12/CXCR4 pathway in the advanced liver disease that is associated with hepatitis $\mathrm{C}$ virus or hepatitis B virus. Eur J Immunol 34, 1164-1174.

167. Bettink SI, Werner C, Chen CH, Müller P, Schirmer SH, Walenta KL, Böhm M, Laufs U, Friedrich EB (2010), Integrin-linked kinase is a central mediator in angiotensin II type 1- and chemokine receptor CXCR4 signaling in myocardial hypertrophy. Biochem Biophys Res Commun 397, 208-213.

168. Katsura M, Shoji F, Okamoto T, Shimamatsu S, Hirai F, Toyokawa G, Morodomi Y, Tagawa T, Oda Y, Maehara Y (2013), Correlation between CXCR4/CXCR7/CXCL12 chemokine axis expression and prognosis in lymph-nodepositive lung cancer patients. Cancer Sci 109, 154-165.

169. Meuris F, Jaracz-Ros A, Gaudin F, Schlecht-Louf G, Deback C, Bachelerie F (2013), The CXCL12/CXCR4 signaling pathway in the control of human papillomavirus infection: new susceptibility factors in viral pathogenesis. Med Sci (Paris) 33, 691-694.

170. Bai R, Liang Z, Yoon Y, Salgado E, Feng A, Gurbani S, Shim H (2013), Novel anti-inflammatory agents targeting CXCR4: design, synthesis, biological evaluation and preliminary pharmacokinetic study. Eur J Med Chem $136,360-371$.

171. Sobolik T, Su YJ, Wells S, Ayers GD, Cook RS, Richmond A (2014), CXCR4 drives the metastatic phenotype in breast cancer through induction of CXCR2 and activation of MEK and PI3K pathways. Mol Biol Cell 25, 566-582.

172. Egeblad M, Werb Z (2002), New functions for the matrix metalloproteinases in cancer progression. Nat Rev Cancer 2, 161-174.

173. Elezkurtaj S, Kopitz C, Baker AH, Perez-Cantó A, Arlt MJ, Khokha R, Gansbacher B, Anton M, Brand K, Krüger A (2004), Adenovirus mediated overexpression of tissue inhibitor of metalloproteinases- 1 in the liver: efficient protection against T-cell lymphoma and colon carcinoma metastasis. J Gene Med 6, 1228-1237.

174. Radisky ES, Raeeszadeh-Sarmazdeh M, Radisky DC (2013), Therapeutic potential of matrix metalloproteinase inhibition in breast cancer. J Cell Biochem 118, 35313548 .

175. Amour A, Knight CG, Webster A, Slocombe PM, Stephens PE, Knäuper V, Docherty AJ, Murphy G (2000), The in vitro activity of ADAM-10 is inhibited by TIMP-1 and TIMP-3. FEBS Lett 473, 275-279. 
176. Chirco R, Liu XW, Jung KK, Kim HR (2006), Novel functions of TIMPs in cell signaling. Cancer Metastasis Rev 25, 99-113.

177. Woessner JF, Taplin CJ (1988), Purification and properties of a small latent matrix metalloproteinase of the rat uterus. J Biol Chem 263, 16918-16925.

178. Yokoyama Y, Grünebach F, Schmidt SM, Heine A, Häntschel M, Stevanovic S, Rammensee HG, Brossart P (2008), Matrilysin (MMP-7) is a novel broadly expressed tumor antigen recognized by antigen-specific T cells. Clin Cancer Res 14, 5503-5511.

179. Ogden SR, Wroblewski LE, Weydig C, Romero-Gallo J, O'Brien DP, Israel DA, Krishna US, Fingleton B, Reynolds AB, Wessler S, Peek RM Jr (2008), p120 and Kaiso regulate Helicobacter pylori-induced expression of matrix metalloproteinase-7. Mol Biol Cell 19, 4110-4121.

180. Yang J, Liu Y (2001), Dissection of key events in tubular epithelial to myofibroblast transition and its implications in renal interstitial fibrosis. Am J Pathol 159, $1465-1475$.

181. Suomalainen K, Sorsa T, Ingman T, Lindy O, Golub LM (1992), Tetracycline inhibition identifies the cellular origin of interstitial collagenases in human periodontal diseases in vivo. Oral Microbiol Immunol 7, 121-123.

182. Golub LM, Sorsa T, Lee HM, Ciancio S, Sorbi D, Ramamurthy NS, Gruber B, Salo T, Konttinen YT (1995), Doxycycline inhibits neutrophil (PMN)-type matrix metalloproteinases in human adult periodontitis gingival. J Clin Periodontol 22, 100-109.

183. Frantz C, Stewart KM, Weaver VM (2010), The extracellular matrix at a glance. J Cell Sci 123, 4195-4200.

184. Gjaltema RA, Bank RA (2013), Molecular insights into prolyl and lysyl hydroxylation of fibrillar collagens in health and disease. Crit Rev Biochem Mol Biol 52, 74-95.

185. Kagan HM (1986), Characterization and regulation of lysyl oxidase, in: RP Mecham (Ed.), Biology of Extracellular Matrix Academic Press, Orlando, Florida, USA, pp. 321398.

186. Miller EJ, Pinnell SR, Martin GR, Schiffmann E (1967), Investigation of the nature of the intermediates involved in desmosine biosynthesis. Biochem Biophys Res Commun 26, 132-137.

187. Pinnell SR, Martin GR, Miller EJ (1968), Desmosine biosynthesis: nature of inhibition by D-penicillamine. Science 161, 475-476.

188. Pinnell SR, Martin GR (1968), The cross-linking of collagen and elastin: enzymatic conversion of lysine in peptide linkage to alpha-aminoadipic-delta-semialdehyde (allysine) by an extract from bone. Proc Natl Acad Sci USA $61,708-716$.

189. Siegel RC, Pinnell SR, Martin GR (1970), Cross-linking of collagen and elastin. Properties of lysyl oxidase. Biochemistry 9, 4486-4492.

190. Chen X, Greenaway FT (2011), Identification of the disulfide bonds of lysyl oxidase. J Neural Transm (Vienna) $118,1111-1114$.

191. Lopez KM, Greenaway FT (2011), Identification of the copper-binding ligands of lysyl oxidase. J Neural Transm (Vienna) 118, 1101-1109.

192. Lucero HA, Kagan HM (2006), Lysyl oxidase: an oxidative enzyme and effector of cell function. Cell Mol Life Sci 63, $2304-2316$.

193. Grimsby JL, Lucero HA, Trackman PC, Ravid K, Kagan HM (2010), Role of lysyl oxidase propeptide in secretion and enzyme activity. J Cell Biochem 111, 1231-1243.
194. Contente S, Csiszar K, Kenyon K, Friedman RM (1993), Structure of the mouse lysyl oxidase gene. Genomics 16 , 395-400.

195. Kenyon K, Modi WS, Contente S, Friedman RM (1993), A novel human cDNA with a predicted protein similar to lysyl oxidase maps to chromosome 15q24-q25. J Biol Chem 268, 18435-18437.

196. Kim Y, Boyd CD, Csiszar K (1995), A new gene with sequence and structural similarity to the gene encoding human lysyl oxidase. J Biol Chem 270, 7176-7182.

197. Csiszar K (2001), Lysyl oxidases: a novel multifunctional amine oxidase family. Prog Nucleic Acid Res Mol Biol 70, $1-32$.

198. Asuncion L, Fogelgren B, Fong KS, Fong SF, Kim Y, Csiszar K (2001), A novel human lysyl oxidase-like gene (LOXL4) on chromosome 10q24 has an altered scavenger receptor cysteine rich domain. Matrix Biol 20, 487-491.

199. Szabó Z, Light E, Boyd CD, Csiszár K (1997), The human lysyl oxidase-like gene maps between STS markers D15S215 and GHLC. GCT7C09 on chromosome 15. Hum Genet 101, 198-200.

200. Hornstra IK, Birge S, Starcher B, Bailey AJ, Mecham RP, Shapiro SD (2003), Lysyl oxidase is required for vascular and diaphragmatic development in mice. J Biol Chem 278, 14387-14393.

201. Kirschmann DA, Seftor EA, Fong SF, Nieva DR, Sullivan CM, Edwards EM, Sommer P, Csiszar K, Hendrix MJ (2002), A molecular role for lysyl oxidase in breast cancer invasion. Cancer Res 62, 4478-4483.

202. Trackman PC, Bedell-Hogan D, Tang J, Kagan HM (1992), Post-translational glycosylation and proteolytic processing of a lysyl oxidase precursor. J Biol Chem 267, 8666-8671.

203. Panchenko MV, Stetler-Stevenson WG, Trubetskoy OV, Gacheru SN, Kagan HM (1996), Metalloproteinase activity secreted by fibrogenic cells in the processing of prolysyl oxidase. Potential role of procollagen C-proteinase. J Biol Chem 271, 7113-7119.

204. Li W, Nellaiappan K, Strassmaier T, Graham L, Thomas KM, Kagan HM (1997), Localization and activity of lysyl oxidase within nuclei of fibrogenic cells. Proc Natl Acad Sci USA 94, 12817-12822.

205. Kagan HM, Li W (2003), Lysyl oxidase: properties, specificity, and biological roles inside and outside of the cell. J Cell Biochem 88, 660-672.

206. Bedell-Hogan D, Trackman P, Abrams W, Rosenbloom J, Kagan H (1993), Oxidation, cross-linking, and insolubilization of recombinant tropoelastin by purified lysyl oxidase. J Biol Chem 268, 10345-10350.

207. Erler JT, Bennewith KL, Cox TR, Lang G, Bird D, Koong A, Le QT, Giaccia AJ (2009), Hypoxia-induced lysyl oxidase is a critical mediator of bone marrow cell recruitment to form the premetastatic niche. Cancer Cell $15,35-44$.

208. Payne SL, Hendrix MJC, Kirschmann DA (2007), Paradoxical roles for lysyl oxidase in cancer - a prospect. J Cell Biochem 101, 1338-1354.

209. Galán M, Varona S, Guadall A, Orriols M, Navas M, Aguiló S, de Diego A, Navarro MA, García-Dorado D, Rodríguez-Sinovas A, Martínez-González J, Rodriguez C (2013), Lysyl oxidase overexpression accelerates cardiac remodeling and aggravates angiotensin II-induced hypertrophy. FASEB J 31, 3787-3799.

210. Rosenkranz S (2004), TGF-beta1 and angiotensin networking in cardiac remodeling. Cardiovasc Res 63, 423-432. 
211. Erler JT, Weaver VM (2009), Three-dimensional context regulation of metastasis. Clin Exp Metastasis $26,35-49$.

212. Butcher DT, Alliston T, Weaver VM (2009), A tense situation: forcing tumour progression. Nat Rev Cancer 9, $108-122$

213. Kothapalli CR, Ramamurthi A (2009), Lysyl oxidase enhances elastin synthesis and matrix formation by vascular smooth muscle cells. J Tissue Eng Regen Med 3, 655-661.

214. Wilgus ML, Borczuk AC, Stoopler M, Ginsburg M, Gorenstein L, Sonett JR, Powell CA (2011), Lysyl oxidase: a lung adenocarcinoma biomarker of invasion and survival. Cancer 117, 2186-2191.

215. Cox TR, Rumney RMH, Schoof EM, Perryman L, Høye AM, Agrawal A, Bird D, Latif NA, Forrest H, Evans HR, Huggins ID, Lang G, Linding R, Gartland A, Erler JT (2015), The hypoxic cancer secretome induces premetastatic bone lesions through lysyl oxidase. Nature $522,106-110$.

216. Xie JJ, Guo JC, Wu ZY, Xu XE, Wu JY, Chen B, Ran LQ, Liao LD, Li EM, Xu LY (2016), Integrin $\alpha 5$ promotes tumor progression and is an independent unfavorable prognostic factor in esophageal squamous cell carcinoma. Hum Pathol 48, 69-75.

217. Nishioka T, Eustace A, West C (2012), Lysyl oxidase: from basic science to future cancer treatment. Cell Struct Funct 37, 75-80.

218. Chen H, Li D, Saldeen T, Mehta JL (2001), Transforming growth factor-beta(1) modulates oxidatively modified LDL-induced expression of adhesion molecules: role of LOX-1. Circ Res 89, 1155-1160.

219. Grimsby JL, Lucero HA, Trackman PC, Ravid K, Kagan HM (2010), Role of lysyl oxidase propeptide in secretion and enzyme activity. J Cell Biochem 111, 1231-1243.

220. Lucero HA, Ravid K, Grimsby JL, Rich CB, DiCamillo SJ, Mäki JM, Myllyharju J, Kagan HM (2008), Lysyl oxidase oxidizes cell membrane proteins and enhances the chemotactic response of vascular smooth muscle cells. J Biol Chem 283, 24103-24117.

221. Lucero HA, Mäki JM, Kagan HM (2011), Activation of cellular chemotactic responses to chemokines coupled with oxidation of plasma membrane proteins by lysyl oxidase. J Neural Transm (Vienna) 118, 1091-1099.

222. Wu G, Guo Z, Chang X, Kim MS, Nagpal JK, Liu J, Maki JM, Kivirikko KI, Ethier SP, Trink B, Sidransky D (2007), LOXL1 and LOXL4 are epigenetically silenced and can inhibit ras/extracellular signal-regulated kinase signaling pathway in human bladder cancer. Cancer Res 67, 41234129 .

223. Mammoto T, Jiang E, Jiang A, Mammoto A (2013), ECM structure and tissue stiffness control postnatal lung development through the LRP5-Tie2 signaling system. Am J Respir Mol Biol 49, 1009-1018.

224. Chen LC, Tu SH, Huang CS, Chen CS, Ho CT, Lin HW, Lee $\mathrm{CH}$, Chang $\mathrm{HW}$, Chang $\mathrm{CH}, \mathrm{Wu} \mathrm{CH}$, Lee WS, Ho YS (2012), Human breast cancer cell metastasis is attenuated by lysyl oxidase inhibitors through down-regulation of focal adhesion kinase and the paxillin-signaling pathway. Breast Cancer Res Treat 134, 989-1004.

225. Chene G, Caloone J, Moret S, Le Bail-Carval K, Chabert P, Beaufils E, Mellier G, Lamblin G (2016), Is endometriosis a precancerous lesion? Perspectives and clinical implications. Gynecol Obstet Fertil 44, 106-112.

226. Ruiz LA, Dutil J, Ruiz A, Fourquet J, Abac S, Laboy J, Flores I (2011), Single-nucleotide polymorphisms in the lysyl oxidase-like protein 4 and complement component 3 genes are associated with increased risk for endometriosis and endometriosis-associated infertility. Fertil Steril 96, $512-515$.

227. Ruiz LA, Báez-Vega PM, Ruiz A, Peterse DP, Monteiro JB, Bracero N, Beauchamp P, Fazleabas AT, Flores I (2015), Dysregulation of lysyl oxidase expression in lesions and endometrium of women with endometriosis. Reprod Sci 22, 1496-1508.

228. Liu X, Shen M, Qi Q, Zhang H, Guo SW (2016), Corroborating evidence for platelet-induced epithelialmesenchymal transition and fibroblast-to-myofibroblast transdifferentiation in the development of adenomyosis. Hum Reprod 31, 734-749.

229. Manov I, Hirsh M, Iancu TC, Malik A, Sotnichenko N, Band M, Avivi A, Shams I (2013), Pronounced cancer resistance in a subterranean rodent, the blind mole-rat, Spalax: in vivo and in vitro evidence. BMC Biol 11, 91.

230. Peyrol S, Raccurt M, Gerard F, Gleyzal C, Grimaud JA, Sommer P (1997), Lysyl oxidase gene expression in the stromal reaction to in situ and invasive ductal breast carcinoma. Am J Pathol 150, 497-507.

231. Tian X, Azpurua J, Hine C, Vaidya A, Myakishev-Rempel M, Ablaeva J, Mao Z, Nevo E, Gorbunova V, Seluanov A (2013), High-molecular-mass hyaluronan mediates the cancer resistance of the naked mole rat. Nature 499, $346-349$.

232. Mitchell BS, Whitehouse A, Prehm P, Delpech B, Schumacher U (1996), CD44 exon variant 6 epitope and hyaluronate synthase are expressed on HT29 human colorectal carcinoma cells in a SCID mouse model of metastasis formation. Clin Exp Metastasis 14, 107-114.

233. Jacobson A, Rahmanian M, Rubin K, Heldin P (2002), Expression of hyaluronan synthase 2 or hyaluronidase 1 differentially affect the growth rate of transplantable colon carcinoma cell tumors. Int J Cancer 102, $212-219$

234. Setälä LP, Tammi MI, Tammi RH, Eskelinen MJ, Lipponen PK, Agren UM, Parkkinen J, Alhava EM, Kosma VM (1999), Hyaluronan expression in gastric cancer cells is associated with local and nodal spread and reduced survival rate. Br J Cancer 79, 1133-1138.

235. Twarock S, Freudenberger T, Poscher E, Dai G, Jannasch K, Dullin C, Alves F, Prenzel K, Knoefel WT, Stoecklein NH, Savani RC, Homey B, Fischer JW (2011), Inhibition of oesophageal squamous cell carcinoma progression by in vivo targeting of hyaluronan synthesis. Mol Cancer 10,30 .

236. Auvinen P, Tammi R, Parkkinen J, Tammi M, Agren U, Johansson R, Hirvikoski P, Eskelinen M, Kosma VM (2000), Hyaluronan in peritumoral stroma and malignant cells associates with breast cancer spreading and predicts survival. Am J Pathol 156, 529-536.

237. Udabage L, Brownlee GR, Nilsson SK, Brown TJ (2005), The over-expression of HAS2, Hyal-2 and CD44 is implicated in the invasiveness of breast cancer. Exp Cell Res 310, 205-217.

238. Li P, Xiang T, Li H, Li Q, Yang B, Huang J, Zhang X, Shi Y, Tan J, Ren G (2015), Hyaluronan synthase 2 overexpression is correlated with the tumorigenesis and metastasis of human breast cancer. Int J Clin Exp Pathol $8,12101-12114$

239. Vanneste M, Hanoux V, Bouakka M, Bonnamy PJ (2013), Hyaluronate synthase-2 overexpression alters estrogen dependence and induces histone deacetylase inhibitor-like effects on ER-driven genes in MCF7 breast tumor cells. Mol Cell Endocrinol 444, 48-58. 
240. Zhu G, Wang S, Chen J, Wang Z, Liang X, Wang X, Jiang J, Lang J, Li L (2013), Long noncoding RNA HAS2-AS1 mediates hypoxia-induced invasiveness of oral squamous cell carcinoma. Mol Carcinog 56, 2210-2222.

241. Anttila MA, Tammi RH, Tammi MI, Syrjänen KJ, Saarikoski SV, Kosma VM (2000), High levels of stromal hyaluronan predict poor disease outcome in epithelial ovarian cancer. Cancer Res 60, 150-155.

242. Clarris BJ, Fraser JR, Rodda S (1974), Effect of cellbound hyaluronic acid on infectivity of Newcastle disease virus for human synovial cells in vitro. Ann Rheum Dis 33, 240-242.

243. Yang B, Zhang L, Turley EA (1993), Identification of two hyaluronan-binding domains in the hyaluronan receptor RHAMM. J Biol Chem 268, 8617-8623.

244. Entwistle J, Hall CL, Turley EA (1996), HA receptors: regulators of signalling to the cytoskeleton. J Cell Biochem 61, 569-577.

245. Weigel PH, Hascall VC, Tammi M (1997), Hyaluronan synthases. J Biol Chem 272, 13997-14000.

246. Udabage L, Brownlee GR, Waltham M, Blick T, Walker EC, Heldin P, Nilsson SK, Thompson EW, Brown TJ (2005), Antisense-mediated suppression of hyaluronan synthase 2 inhibits the tumorigenesis and progression of breast cancer. Cancer Res 65, 6139-6150.

247. Katsuno Y, Qin J, Oses-Prieto J, Wang H, JacksonWeaver O, Zhang T, Lamouille S, Wu J, Burlingame A, Xu J, Derynck R (2018), Arginine methylation of SMAD7 by PRMT1 in TGF- $\beta$-induced epithelial-mesenchymal transition and epithelial stem-cell generation. J Biol Chem 293, 13059-13072.

248. Rodriguez KA, Li K, Nevo E, Buffenstein R (2016), Mechanisms regulating proteostasis are involved in sympatric speciation of the blind mole rat, Spalax galili. Autophagy 12, 703-704.

249. Li YX, Zhang L, Simayi D, Zhang N, Tao L, Yang L, Zhao J, Chen YZ, Li F, Zhang WJ (2015), Human papillomavirus infection correlates with inflammatory Stat3 signaling activity and IL-17 level in patients with colorectal cancer. PLoS ONE 10, e0118391.

250. Nojiri T, Hosoda H, Tokudome T, Miura K, Ishikane S, Otani K, Kishimoto I, Shintani Y, Inoue M, Kimura T, Sawabata N, Minami M, Nakagiri T, Funaki S, Takeuchi Y, Maeda H, Kidoya H, Kiyonari H, Shioi G, Arai Y, Hasegawa T, Takakura N, Hori M, Ohno Y, Miyazato M, Mochizuki N, Okumura M, Kangawa K (2015), Atrial natriuretic peptide prevents cancer metastasis through vascular endothelial cells. Proc Natl Acad Sci USA 112, 4086-4091.

251. Lu P, Weaver VM, Werb Z (2012), The extracellular matrix: a dynamic niche in cancer progression. J Cell Biol 196, 395-406.

252. Nakagawa H, Hikiba Y, Hirata Y, Font-Burgada J, Sakamoto K, Hayakawa Y, Taniguchi K, Umemura A, Kinoshita H, Sakitani K, Nishikawa Y, Hirano K, Ikenoue T, Ijichi H, Dhar D, Shibata W, Akanuma M, Koike K, Karin M, Maeda S (2014), Loss of liver E-cadherin induces sclerosing cholangitis and promotes carcinogenesis. PNAS 111, 1090-1095.

253. Joo YN, Jin H, Eun SY, Park SW, Chang KC, Kim HJ (2014), P2Y2R activation by nucleotides released from the highly metastatic breast cancer cell contributes to premetastatic niche formation by mediating lysyl oxidase secretion, collagen crosslinking, and monocyte recruitment. Oncotarget 5, 9322-9334.

254. Eun SY, Ko YS, Park SW, Chang KC, Kim HJ (2015), P2Y2 nucleotide receptor-mediated extracellular signal- regulated kinases and protein kinase $\mathrm{C}$ activation induces the invasion of highly metastatic breast cancer cells. Oncol Rep 34, 195-202.

255. Salvador F, Martin A, López-Menéndez C, Moreno-Bueno G, Santos V, Vázquez-Naharro A, Santamaria PG, Morales S, Dubus PR, Muinelo-Romay L, López-López R, Tung JC, Weaver VM, Portillo F, Cano A (2013), Lysyl oxidase-like protein LOXL2 promotes lung metastasis of breast cancer. Cancer Res 77, 5846-5859.

256. Park JS, Lee JH, Lee YS, Kim JK, Dong SM, Yoon DS (2013), Emerging role of LOXL2 in the promotion of pancreas cancer metastasis. Oncotarget 7, 42539-42552.

257. Barry-Hamilton V, Spangler R, Marshall D, Marshall D, McCauley S, Rodriguez HM, Oyasu M, Mikels A, Vaysberg M, Ghermazien H, Wai C, Garcia CA, Velayo AC, Jorgensen B, Biermann D, Tsai D, Green J, ZaffryarEilot S, Holzer A, Ogg S, Thai D, Neufeld G, Van Vlasselaer P, Smith V (2010), Allosteric inhibition of lysyl oxidase-like-2 impedes the development of a pathologic microenvironment. Nat Med 16, 1009-1017.

258. Dongiovanni P, Meroni M, Baselli GA, Bassani GA, Rametta R, Pietrelli A, Maggioni M, Facciotti F, Trunzo V, Badiali S, Fargion S, Gatti S, Valenti L (2013), Insulin resistance promotes Lysyl Oxidase Like 2 induction and fibrosis accumulation in non-alcoholic fatty liver disease. Clin Sci (Lond) 131, 1301-1315.

259. Rodriguez HM, Vaysberg M, Mikels A, McCauley S, Velayo AC, Garcia C, Smith V (2010), Modulation of lysyl oxidase-like 2 enzymatic activity by an allosteric antibody inhibitor. J Biol Chem 285, 20964-20974.

260. Sommer P, Gleyzal C, Raccurt M, Delbourg M, Serrar M, Joazeiro P, Peyrol S, Kagan H, Trackman PC, Grimaud JA (1993), Transient expression of lysyl oxidase by liver myofibroblasts in murine schistosomiasis. Lab Invest 69, 460-470.

261. Ouzzine M, Boyd A, Hulmes DJ (1996), Expression of active, human lysyl oxidase in Escherichia coli. FEBS Lett 399, 215-219.

262. Saito H, Papaconstantinou J, Sato H, Goldstein S (1997), Regulation of a novel gene encoding a lysyl oxidase-related protein in cellular adhesion and senescence. J Biol Chem 272, 8157-8160.

263. Decitre M, Gleyzal C, Raccurt M, Peyrol S, AubertFoucher E, Csiszar K, Sommer P (1998), Lysyl oxidaselike protein localizes to sites of de novo fibrinogenesis in fibrosis and in the early stromal reaction of ductal breast carcinomas. Lab Invest 78, 143-151.

264. Salvador F, Martin A, López-Menéndez C, Moreno-Bueno G, Santos V, Vázquez-Naharro A, Santamaria PG, Morales S, Dubus PR, Muinelo-Romay L, López-López R, Tung JC, Weaver VM, Portillo F, Cano A (2013), Lysyl oxidase-like protein LOXL2 promotes lung metastasis of breast cancer. Cancer Res 77, 5846-5859.

265. Milward MR, Chapple IL, Carter K, Matthews JB, Cooper PR (2013), Micronutrient modulation of NF- $\kappa$ B in oral keratinocytes exposed to periodontal bacteria. Innate Immun 19, 140-151.

266. Willumsen N, Thomsen LB, Bager CL, Jensen C, Karsdal MA (2013), Quantification of altered tissue turnover in a liquid biopsy: a proposed precision medicine tool to assess chronic inflammation and desmoplasia associated with a pro-cancerous niche and response to immuno-therapeutic anti-tumor modalities. Cancer Immunol Immunother 67, $1-12$.

267. Mahato K, Kumar A, Maurya PK, Chandra P (2013), Shifting paradigm of cancer diagnoses in clinically relevant samples based on miniaturized electrochemical 
nanobiosensors and microfluidic devices. Biosens Bioelectron 100, 411-428.

268. Jing CY, Fu YP, Huang JL, Zhang MX, Yi Y, Gan W, Xu X, Shen HJ, Lin JJ, Zheng SS, Zhang J, Zhou J, Fan J, Ren ZG, Qiu SJ, Zhang BH (2018), Prognostic nomogram based on histological characteristics of fibrotic tumor stroma in patients who underwent curative resection for intrahepatic cholangiocarcinoma. Oncologist. DOI: 10.1634/theoncologist.2017-0439

269. Pankova D, Chen Y, Terajima M, Schliekelman MJ, Baird BN, Fahrenholtz M, Sun L, Gill BJ, Vadakkan TJ, Kim MP, Ahn YH, Roybal JD, Liu X, Parra Cuentas ER, Rodriguez J, Wistuba II, Creighton CJ, Gibbons DL, Hicks JM, Dickinson ME, West JL, Grande-Allen KJ, Hanash SM, Yamauchi M, Kurie JM (2016), Mol Cancer Res 14, 287-295.

270. Tan X, Banerjee P, Guo HF, Ireland S, Pankova D, Ahn YH, Nikolaidis IM, Liu X, Zhao Y, Xue Y, Burns AR, Roybal J, Gibbons DL, Zal T, Creighton CJ, Ungar D, Wang Y, Kurie JM (2013), Epithelial-to-mesenchymal transition drives a pro-metastatic Golgi compaction process through scaffolding protein PAQR11. J Clin Invest 127, 117-131.

271. Yamauchi M, Barker TH, Gibbons DL, Kurie JM (2018), The fibrotic tumor stroma. J Clin Invest 128, 16-25.

272. Wei Y, Kim TJ, Peng DH, Duan D, Gibbons DL, Yamauchi M, Jackson JR, Le Saux CJ, Calhoun C, Peters J, Derynck R, Backes BJ, Chapman HA (2013), Fibroblast-specific inhibition of TGF- $\beta 1$ signaling attenuates lung and tumor fibrosis. J Clin Invest 127, 3675-3688.

273. Kim DJ, Lee DC, Yang SJ, Lee JJ, Bae EM, Kim DM, Min SH, Kim SJ, Kang DC, Sang BC, Myung PK, Park KC, Yeom YI (2008), Lysyl oxidase like 4, a novel target gene of TGF-beta1 signaling, can negatively regulate TGF-beta1induced cell motility in $\mathrm{PLC} / \mathrm{PRF} / 5$ hepatoma cells. Biochem Biophys Res Commun 373, 521-527.

274. Yang X, Li S, Li W, Chen J, Xiao X, Wang Y, Yan G, Chen L (2013), Inactivation of lysyl oxidase by $\beta$-aminopropionitrile inhibits hypoxia-induced invasion and migration of cervical cancer cells. Oncol Rep 29, 541-548.

275. Erler JT, Giaccia AJ (2006), Lysyl oxidase mediates hypoxic control of metastasis. Cancer Res 66, 10238-10241.

276. Erler JT, Bennewith KL, Nicolau M, Dornhöfer N, Kong C, Le QT, Chi JT, Jeffrey SS, Giaccia AJ (2006), Lysyl oxidase is essential for hypoxia-induced metastasis. Nature 440, 1222-1226.

277. Ikenaga N, Peng ZW, Vaid KA, Liu SB, Yoshida S, Sverdlov DY, Mikels-Vigdal A, Smith V, Schuppan D, Popov YV (2013), Selective targeting of lysyl oxidase-like 2 (LOXL2) suppresses hepatic fibrosis progression and accelerates its reversal. Gut 66, 1697-1708.

278. El Hajj EC, El Hajj MC, Ninh VK, Gardner JD (2018), Inhibitor of lysyl oxidase improves cardiac function and the collagen/MMP profile in response to volume overload. Am J Physiol Heart Circ Physiol 315, H463-H473.

279. Ma L, Zeng Y, Wei J, Yang D, Ding G, Liu J, Shang J, Kang Y, Ji X (2018), Knockdown of LOXL1 inhibits TGF$\beta 1$-induced proliferation and fibrogenesis of hepatic stellate cells by inhibition of Smad2/3 phosphorylation. Biomed Pharmacother 107, 1728-1735.

280. Stangenberg S, Saad S, Schilter HC, Zaky A, Gill A, Pollock CA, Wong MG (2018), Lysyl oxidase-like 2 inhibition ameliorates glomerulosclerosis and albuminuria in diabetic nephropathy. Sci Rep 8, 9423.

281. Zhao W, Yang A, Chen W, Wang P, Liu T, Cong M, Xu A, Yan X, Jia J, You H (2018), Inhibition of lysyl oxidase-like 1 (LOXL1) expression arrests liver fibrosis progression in cirrhosis by reducing elastin crosslinking. Biochim Biophys Acta Mol Basis Dis 1864, 1129-1137.

282. Rachman-Tzemah C, Zaffryar-Eilot S, Grossman M, Ribero D, Timaner M, Mäki JM, Myllyharju J, Bertolini F, Hershkovitz D, Sagi I, Hasson P, Shaked Y (2013), Blocking surgically induced lysyl oxidase activity reduces the risk of lung metastases. Cell Rep 19, 774-784.

283. Zhang L, Wang Y, Xia T, Yu Q, Zhang Q, Yang Y, Cun X, Lu L, Gao H, Zhang Z, He Q (2016), Suppression for lung metastasis by depletion of collagen I and lysyl oxidase via losartan assisted with paclitaxel-loaded $\mathrm{pH}-$ sensitive liposomes in breast cancer. Drug Deliv 23, 2970-2979.

284. Xu Y, Wang X, Huang Y, Ma Y, Jin X, Wang H, Wang J (2018), Inhibition of lysyl oxidase expression by dextran sulfate affects invasion and migration of gastric cancer cells. Int J Mol Med 42, 2737-2749.

285. Hajdú I, Kardos J, Major B, Fabó G, Lőrincz Z, Cseh S, Dormán G (2018), Inhibition of the LOX enzyme family members with old and new ligands. Selectivity analysis revisited. Bioorg Med Chem Lett 28, 3113-3118.

286. Sarenac T, Trapecar M, Gradisnik L, Rupnik MS, Pahor D (2016), Single-cell analysis reveals IGF-1 potentiation of inhibition of the TGF- $\beta$ /Smad pathway of fibrosis in human keratocytes in vitro. Sci Rep 6, 1-12.

287. Srivatsa S, Paul MC, Cardone C, Holcmann M, Amberg N, Pathria P, Diamanti MA, Linder M, Timelthaler G, Dienes HP, Kenner L, Wrba F, Prager GW, Rose-John S, Eferl R, Liguori G, Botti G, Martinelli E, Greten FR, Ciardiello F, Sibilia M (2013), EGFR in Tumor-associated myeloid cells promotes development of colorectal cancer in mice and associates with outcomes of patients. Gastroenterology 153, 178-190.

288. De Donato M, Petrillo M, Martinelli E, Filippetti F, Zannoni GF, Scambia G, Gallo D (2013), Uncovering the role of nuclear Lysyl oxidase (LOX) in advanced high grade serous ovarian cancer. Gynecol Oncol 146, 170-178.

289. Lee YS, Park Y, Kwon M, Roh JL, Choi SH, Nam SY, Kim SY (2013), Expression of lysyl oxidase predictive of distant metastasis of laryngeal cancer. Otolaryngol Head Neck Surg 156, 489-497.

290. Brücher BLDM, Jamall IS (2019), Chronic inflammation evoked by pathogenic stimulus during carcinogenesis. 4open 2, 8, 1-22. https://doi.org/10.1051/fopen/2018006

291. Fallowfield LJ, Fleissig A (2011), The value of progression-free survival to patients with advanced-stage cancer. Nat Rev Clin Oncol 9, 41-47.

292. Brücher BLDM, Jamall IS (2019), Eicosanoids in carcinogenesis. 4open 2, 9, 1-34. https://doi.org/10.1051/fopen/ 2018008

293. Brücher BLDM, Jamall IS (2019), Undervalued ubiquitous proteins. 4open 2, 7, 1-13, https://doi.org/10.1051/ fopen $/ 2019002$

294. Brücher BLDM, Jamall IS (2019), Microbiome and morbid obesity increase pathogenic stimulus diversity. 4open 2, 10, 1-16. https://doi.org/10.1051/fopen/2018007

Cite this article as: Brücher BLDM, Jamall IS. (2019), Precancerous niche (PCN), a product of fibrosis with remodeling by incessant chronic inflammation. 4open, 2, 11. 